\title{
The Catalysed Transformation of Vegetable Oils or Animal Fats to Biofuels and Bio-Lubricants: A Review
}

\author{
Martin Hájek 1,*D, Aleš Vávra ${ }^{1}$, Héctor de Paz Carmona ${ }^{2} \mathbb{D}$ and Jaroslav Kocík ${ }^{2} \mathbb{D}$ \\ 1 Department of Physical Chemistry, Faculty of Chemical Technology, University of Pardubice, Studentská 573, \\ 53210 Pardubice, Czech Republic; ales.vavra@upce.cz \\ 2 ORLEN UniCRE, Inc., Revoluční 1521/84, 40001 Ústí nad Labem, Czech Republic; \\ Hector.Carmona@unicre.cz (H.d.P.C.); Jaroslav.Kocik@unicre.cz (J.K.) \\ * Correspondence: martin.hajek@upce.cz
}

check for

updates

Citation: Hájek, M.; Vávra, A.; de Paz Carmona, H.; Kocík, J. The Catalysed Transformation of Vegetable Oils or Animal Fats to Biofuels and Bio-Lubricants: A Review. Catalysts 2021, 11, 1118 https://doi.org/10.3390/catal 11091118

Academic Editor: Christiaan Tempelman

Received: 27 August 2021

Accepted: 13 September 2021

Published: 17 September 2021

Publisher's Note: MDPI stays neutral with regard to jurisdictional claims in published maps and institutional affiliations.

Copyright: (c) 2021 by the authors. Licensee MDPI, Basel, Switzerland. This article is an open access article distributed under the terms and conditions of the Creative Commons Attribution (CC BY) license (https:/ / creativecommons.org/licenses/by/ $4.0 /)$.

\begin{abstract}
This review paper summarizes the current state-of-the-art of the chemical transformation of oils/fats (i.e., triacylglycerols) to the use of biofuels or bio-lubricants in the means of transport, which is a novelty. The chemical transformation is necessary to obtain products that are more usable with properties corresponding to fuels synthesized from crude oil. Two types of fuels are describedbiodiesel (the mixture of methyl esters produced by transesterification) and green diesel (paraffins produced by hydrogenation of oils). Moreover, three bio-lubricant synthesis methods are described. The transformation, which is usually catalysed, depends on: (i) the type and composition of the raw material, including alcohols for biodiesel production and hydrogen for green diesel; (ii) the type of the catalyst in the case of catalysed reactions; (iii) the reaction conditions; and (iv) types of final products. The most important catalysts, especially heterogeneous and including reaction conditions, for each product are described. The properties of biodiesel and green diesel and a comparison with diesel from crude oil are also discussed.
\end{abstract}

Keywords: oils/fats; transesterification; biodiesel; hydrotreating; green diesel; bio-lubricants

\section{Introduction}

The world's energy consumption is ceaselessly rising from the industrial revolution in the 18th century. In the last several decades, world energy consumption increased by about $5 \%$ per year [1,2]. Many scientists worldwide are trying to find new sources of renewable energy which could replace fossil fuels [3]. Non-renewable resources, including fossil fuels (coal, oil, natural gas, among others), are found in limited reserves and can be depleted, unlike renewable resources, which cannot be depleted. Renewable energy belongs to the natural resources that can naturally recover in a human time-scale. They provide several key objectives: (i) security of energy supply, (ii) the reduction of greenhouse gases, (iii) the reduction of energy prices, and (iv) the possibility of new jobs and general economic growth [4]. This kind of energy can be obtained from sunlight, wind, geothermal resources, oceans, hydropower, and so forth. The definition of renewable resources could be as follows: Renewable natural resources can recover partially or entirely from their consumption, either alone or with human contribution [5]. Humans have used renewable resources (wood) since prehistoric times, but population growth has increased the need for deforestation. Paradoxically, this big issue was resolved by fossil fuels, which allowed to gain energy in other ways than from growing crops, which requires a large area of land.

The first-generation biofuels (mainly produced from food crops) have a limited ability to replace fossil fuels, reduce climate change, and encourage economic growth. Biofuels include bioethanol (produced from grain, sugar beet, sugar cane, corn, starch, etc.), rapeseed oil methyl ester, and fatty acid methyl ester (FAME) (produced from pressed oil plants-palm oil, sunflower oil, soybean oil, etc.) [6]. Bioethanol is widely used in the USA and Brazil, which utilize the excess of sugar cane. In Europe, biodiesel is primarily used 
as biofuel [7]. In the European Union, the importance and consumption of biofuels are constantly growing, as currently, $7 \mathrm{wt} \%$ has to be blended into diesel by producers [8]. The main associated problems are the following: (i) not enough growing land to replace crude oil, (ii) large amounts of raw material, (iii) ability to compete with food production, and (iv) the use of fertilizers or pesticide for growing.

Problems related to first-generation biofuels have increased for developing biofuels produced from non-edible food crops and forest biomass, including mining residues, agricultural waste (straw, hay, corn, and others), and fast-growing grasses and wood or biological waste from households. These so-called second-generation fuels include bioethanol, diesel oil as a product of Fisher-Tropsch synthesis, biobutanol from bioethanol, and so forth. The second-generation energy crops have a greater potential to replace crude oil than those of the first generation. The main issue is that the technological process is more complicated than for the first generation. Although significant progress has been made, many technical problems still have to be eliminated and overcome so that these crops can be used commercially $[9,10]$. The second generation requires less land than the first, but the required land for production is still substantial.

The problems associated with production and using first-generation fuels can be solved by third-generation biofuels, which use fast-growing microorganisms (algae, cyanobacteria). This category of biofuels includes microalgae and various types of bacteria that can produce hydrocarbon-based fuel from $\mathrm{CO}_{2}$ and sunlight $[11,12]$.

In line with the ambitious new European Union, targets related to the use of renewable energy have increased to $12 \%$ of renewable sources consumption in 2030, which is an increase in the amount of biomass used [13]. The consumption of renewable energy is also increasing in the USA [14].

The novelty of the review consists in the description and comparison of the ways of transforming oils/fats to biofuels (biodiesel and Green Diesel) and biolubricants used in the means of transport. Other reviews are focused on one product only, one type of oil [15], one method of transformation, one aspect of biodiesel, or one type of catalyst [16]. The review gives a general overview of oils/fats transformation.

\section{Raw Material-The Vegetable Oils and Animal Fats}

The main raw materials for producing biodiesel and green diesel are triacylglycerols (also called triglycerides), which are contained in vegetable oils and animal fats. The oils/fats are usually sorted into (i) edible oils (such as rapeseed, soybean, sunflower, palm, etc.), (ii) nonedible oils (such as Jatropha curcas L., Pongamia pinnata, Ricinus communis, etc.) [17], (iii) waste cooking oils [18], (iv) animal fats, or (v) oil formed by microalgae, which are rapidly expanding raw materials, such as algae and cyanobacteria (oil extracted from them) [19].

The oils/fats usually contain approximately $98 \%$ of triacylglycerols (chemically, esters of higher fatty acids and glycerol). Other chemical matters are mono- and diacylglycerols, free fatty acids, water, dyes, and so forth. The profile of higher fatty acid, bonded in triacylglycerols, determines physical-chemical properties such as viscosity, iodine number, and oxidative stability $[20,21]$. The concrete composition of oil, including the FA profile, depends on the type of oils/fats, and the type of cultivar, the condition of storing and growing (for vegetable oils) - for example, the content of oleic acid in rapeseed oil (RSO) can range from $45 \%$ to $61 \%$ [22] - therefore, only the average contents of the major common fatty acids are shown in Table 1. The composition of the other oil is stated in [1]. The fatty acids were sorted by (i) saturated (the most abundant are palmitic and stearic) and (ii) unsaturated (mainly represented by oleic, linoleic, and linolenic acids). The composition of oils/fats is important because they influence the reaction conditions of the following processes.

The free fatty acids (FFA) are not bound through glycerol, and their content is very variable from almost 0 to $90 \mathrm{wt} \%$, for example, RSO contains usually $0.5-1.0 \mathrm{wt} \%$ of FFA, and tropical oil usually contains $2-5 \mathrm{wt} \%$. However, some vegetable oils contain more than $90 \%$ of the FFA (e.g., tall oil fatty acid (TOFA) [23]). 
Table 1. The content of fatty acids in various types of vegetable oils and animal fats $[22,24]$.

\begin{tabular}{|c|c|c|c|c|c|}
\hline \multirow{2}{*}{ Oil/Fat } & \multicolumn{5}{|c|}{ The Content of Major Fatty Acid, \% } \\
\hline & Palmitic (16:0) * & Stearic (18:0) & Oleic (18:1) & Linoleic (18:2) & Linolenic (18:3) \\
\hline Palm & 45 & 8 & 38 & 10 & 0.5 \\
\hline Soybean & 10 & 4 & 21 & 56 & 8 \\
\hline Rapeseed & 4.5 & 1.5 & 56 & 21 & 10 \\
\hline Sunflower & 6.5 & 5 & 24 & 63 & 0.3 \\
\hline Olive & 11.5 & 2.5 & 74 & 9.5 & 1.5 \\
\hline Jatropha oil & 15.4 & 5 & 37 & 42.2 & 0.3 \\
\hline Camelina sativa & 8.3 & 0.5 & 19.5 & 46.5 & 25.1 \\
\hline Lard & 24 & 14 & 44 & 10.7 & 0.4 \\
\hline Beef tallow & 26 & 20 & 40 & 4.5 & 0.5 \\
\hline Mutton tallow & 27 & 32 & 32 & 1.6 & 0.2 \\
\hline
\end{tabular}

* The fatty acids are abbreviated: the first number indicates the number of carbon atoms and the second number is the number of double bonds.

The concrete sources of oil/fat depend on the area-rapeseed oil is mainly used in Europe, soybean oil in the USA, and palm oil in Malaysia. The price of biodiesel and green diesel strongly depends on oil/fat (approximately $80-85 \%$ of biofuel prices consist of the price of oil). Therefore, newer and cheaper sources are searched for, such as jatropha and TOFA. However, their use is disputable because they usually contain more impurities, especially free fatty acids and water, which complicate further usage.

The vegetable oils can be obtained in various ways, either from the pulps of fruits (palm, olive), from seeds of vegetables (rapeseed, sunflower), or also from beans (soy). The pulp oil is obtained by pressing, which has to be carried out in the place of planting because of the meagre shelf life of the fruit pulp. By contrast, oilseeds and beans can be stored and transported almost unlimitedly. There are two technologies which are mostly widespread in the industry worldwide: (i) pressing with continuous screw presses [25] and (ii) extracting of hydrocarbons (usually fraction C6) [26]. A combination of pressing followed by solvent extraction is used to obtain large volumes; it is possible to achieve a yield of $98 \%$ of the oil contained in the raw materials. On a local scale, the producers mainly use a pressing technology to obtain $85 \%$ of the contained oil in the raw materials.

The first step for waste cooking oils and animal fats is decantation and filtration to remove food scraps and frying waste. This operation is commonly done by local waste managers, which are in charge of collecting this residue from houses and restaurants. For the preparation of esters, the phospholipids and slime components are removed by degumming. The crude oil is also necessary to refine (at least partially) for the production of FAME [27-29]. Moreover, vegetable oils usually contain natural gums (phosphatides) and other ashes, which are removed throughout oil refining and transesterification. For Green diesel, the high content of metals in the raw material is problematic because it can destroy the catalyst-it has to be reduced by raffinate.

Vegetable oils or animal fats are possible to use directly in an engine, but engine modifications are necessary. The main problems of using oils/fats are (i) high kinematic viscosity (in the range of $30-40 \mathrm{~mm}^{2} \mathrm{~s}^{-1}$ ), (ii) a low cetane number, and (iii) a lower flash point than fuels formed from crude oil. However, to solve problems with high viscosity, it is necessary to transform the oil/fat into fuels with lower viscosity—esters of low molecular alcohols (biodiesel) or green diesel.

\section{The Properties and Comparison of Biodiesel and Green Diesel}

Biodiesel is formed by transesterification (usually catalytic), while green diesel (also known as hydrotreated vegetable oil-HVO) is formed by catalytic hydrotreating of oil. The comparison of the properties of biodiesel, $\mathrm{HVO}$ and standards for diesel in the European Union countries is stated in Table 2, and details about the production are in the following Sections 4 and 5. 
Table 2. Properties of biodiesel, HVO, and fossil diesel (including minimal and maximal standard values for diesel) [1].

\begin{tabular}{|c|c|c|c|c|c|}
\hline Properties & Biodiesel & HVO & Fossil Diesel & Standard Min. & Standard Max. \\
\hline Chemical composition & ester & hydrocarbon & hydrocarbon & - & - \\
\hline Oxygen, wt $\%$ & 11 & 0 & 0 & - & - \\
\hline Density $\left(15^{\circ} \mathrm{C}\right), \mathrm{g} \mathrm{cm}^{-3}$ & $0.86-0.90$ & $0.77-0.83$ & 0.85 & 0.80 & 0.845 \\
\hline Kinematic viscosity $\left(40^{\circ} \mathrm{C}\right), \mathrm{mm}^{2} \mathrm{~s}^{-1}$ & $4.0-5.5$ & $2.5-3.5$ & $2.7-5.5$ & 2.0 & 4.5 \\
\hline Cloud point, ${ }^{\circ} \mathrm{C}$ & -13 to 10 & $>20$ & -6 & -5 & +6 \\
\hline Sulphur content, mg.kg ${ }^{-1}$ & $<0.01$ & $<10$ & 10 & - & 10 \\
\hline Caloric value, $\mathrm{MJ} \mathrm{kg}^{-1}$ & $37.5-38$ & 44 & $44.7-46.7$ & - & - \\
\hline Flash point, ${ }^{\circ} \mathrm{C}$ & $96-188$ & $68-120$ & $52-136$ & 60 & 170 \\
\hline Pour point, ${ }^{\circ} \mathrm{C}$ & -15 to 16 & -3 to 29 & -21 & -13 & 10 \\
\hline Cetane number & 50-65 & 50-105 & $52-136$ & 60 & 170 \\
\hline
\end{tabular}

Note: the exact properties of biodiesel and HVO depend on the type of raw material and the conditions of preparation.

The carbon balance of the products of renewable fuels is zero because carbon dioxide, released during its combustion, is removed from the atmosphere by the photosynthesis of plants and converted back into oil. However, it should be noted that the whole process, that is, seed sowing, plant growth, harvesting, extracting of oil from crops, transesterification, finishing, and final product preparation and transport of all substances, significantly influences the carbon balance (increased carbon dioxide emission). There has been extensive discussion about its environmental benefits [30-32].

The oils/fats formed by biofuels are evaluated by many properties, such as the cloud point $\left({ }^{\circ} \mathrm{C}\right)$, which is the temperature when wax begins to form (the first turbidity appears); the pour point $\left({ }^{\circ} \mathrm{C}\right)$, which is the minimum temperature when the sample has the ability to pour down from a beaker (high pour point is generally associated with a high paraffin content); the flashpoint $\left({ }^{\circ} \mathrm{C}\right)$, which is the lowest temperature when an external source can ignite the vaporized sample; the fire point $\left({ }^{\circ} \mathrm{C}\right)$, which is when the sample is combusted for at least five minutes; the cetane number, which is the indication of the combustion speed of fuel and compression needed for ignition; the acid value $\left(\mathrm{mg} \mathrm{KOH} \mathrm{g}^{-1}\right)$, which reflects the acidity of samples; oxidative stability (h), which is an important parameter that indicates the susceptibility of the fuel to its degradation; and iodine value $\left(\mathrm{mg} \mathrm{I}_{2} \mathrm{~g}^{-1}\right)$, which reflects the number of double bonds.

The HVO is chemically composed of paraffinic hydrocarbons, that is, without oxygen and double bonds in the molecules, which is more similar to fossil diesel and can be used or added to fossil diesel without significant technical limitations to engines. Biodiesel is composed of low alkyl esters of higher fatty acids, containing oxygen and double bonds between atoms of carbonates (they do not contain sulphur or aromatic hydrocarbons). The double bonds are sensitive to humidity and oxygen in the air, which can cause hydrolysis and oxidation during long-term storage (ketones and acids are formed [33]) and so decrease oxidative stability. The low oxidative stability is solved by adding of antioxidants such as sterically hindered phenols, secondary aromatic amines, or butylated hydroxytoluene (Baynox ${ }^{\circledR}$ ).

The HVO has a higher cetane number (almost no content of aromatic hydrocarbons) and lower density (Table 2) than biodiesel [34]. Biodiesel density is about 2-7\% higher than diesel and increases with an increasing number of carbon in the alcohols chain [35]. On the other hand, the low-temperature properties of HVO are worse than those of biodiesel because of the high content of paraffin [36]. This fact determines the limit of $\mathrm{HVO}$ content in diesel blending or implies the addition of additives [37]. The viscosity of biodiesel is comparable to diesel $[38,39]$. However, the biodiesel viscosity also depends on the profile and conformation (cis or trans) of fatty acids and increases with the increasing length of FA and decreases with the increasing number of double bonds [40].

Biodiesel usually has a lower caloric value than diesel, which causes lower performance and higher consumption [41]. Conversely, biodiesel burns better than diesel fuel, thus reducing engine smoke. It was found that biodiesel has lower emissions of carbon dioxide, sulphur, and air pollution [42-44]. On the other hand, the emissions of $\mathrm{NO}_{2}$ 
are significantly higher, but the emissions of $\mathrm{NO}$ are lower compared to diesel fuel. For biodiesel, combustion of the total amount of $\mathrm{NO}_{\mathrm{x}}$ is slightly higher than for diesel fuel combustion $[45,46]$. It should be mentioned that the emissions depend on the oxygen amount during combustion. Biodiesel has a higher lubricity than diesel and therefore reduces engine wear $[47,48]$. It is a good solvent, so it can dissolve the dirt from the engine, which can plug a fuel filter, and it can damage parts of rubber in some engines [49]. The exact chemical composition and properties also depend on biodiesel generation [8].

For biodiesel, the biodegradable in water is significantly shorter than diesel $(95 \%$ of biodiesel degrades compared to $40 \%$ of diesel after 28 days). In water, it does not cause a microbiological load up to a concentration of $10 \mathrm{~g} \mathrm{~L}^{-1}$ [50].

The disadvantage of $\mathrm{HVO}$ consists in the conditions of production; the temperature is usually between 300 and $370{ }^{\circ} \mathrm{C}$ and has a pressure of 2 and $10 \mathrm{MPa}$, which requires more demanding reaction equipment for biodiesel production. Another disadvantage of $\mathrm{HVO}$ is the consumption of hydrogen, which is usually produced from fossil sources and has to be purified before use. On the other hand, the production is insensitive to the quality of vegetable oil (the high content of free fatty acids is not problematic). Biodiesel is most frequently produced by quite undemanding reaction conditions: a cheap, commonly available catalyst $(\mathrm{KOH}$ or $\mathrm{NaOH})$, alcohol (methanol), $60{ }^{\circ} \mathrm{C}$ and standard pressure. However, the production is more sensitive to the quality of the vegetable oil, which strongly influences the method and conditions of transesterification (refer to Section 4.2). Biodiesel can be easily produced by small local companies without advanced technical knowledge, which is not possible for HVO. The disadvantages are the economic cost of the production process, where the most expensive input is vegetable oil (accounts for $85-90 \%$ of the biodiesel cost).

One of the main side-products of $\mathrm{HVO}$ is propane $\left(\mathrm{C}_{3} \mathrm{H}_{8}\right)$, which can be used as a biogas component. For biodiesel, the main side-product is glycerol, which has wide usage in the chemistry, food, and pharmaceutic industries [51]. A detailed description of the production of biodiesel and $\mathrm{HVO}$ is in the following section.

\section{The Ester Production-Transesterification}

The main transesterification product is biodiesel-the methyl esters of unsaturated and saturated fatty acids of vegetable/animal origin. It is produced by transesterification: triacylglycerols (TG) (Equation (1)) react with alcohol (A), and the products are esters (E) and glycerol $(\mathrm{G})$. Transesterification is usually catalysed.

$$
\mathrm{TG}+3 \mathrm{~A} \leftrightarrows \mathrm{G}+3 \mathrm{E}
$$

This reaction proceeds in three consecutive steps during which undesirable compounds, such as diacylglycerols (DG) and monoacylglycerols (MG), are formed (Equation (2)). Note: The abbreviations MG, DG, TG, and E do not mean a pure chemical substance, but the mixture of various acylglycerols or esters of higher fatty acids.

$$
\mathrm{TG}+\mathrm{A} \leftrightarrows \mathrm{DG}+\mathrm{E} \mathrm{DG}+\mathrm{A} \leftrightarrows \mathrm{MG}+\mathrm{EMG}+\mathrm{A} \leftrightarrows \mathrm{G}+\mathrm{E}
$$

As an equilibrium reaction, the transesterification is performed with an excess of alcohol to shift the direction towards the products (the excess depends on the type of catalyst and alcohol) [52]. Two partially miscible phases, which have to be separated, are obtained after transesterification (Section 4.3).

\subsection{Alcohols}

Other raw materials necessary for biodiesel production are low molecular alcohols, such as methanol, ethanol, and butanol, which are mostly published (Table 3). Methanol is mainly used due to its lower cost and its appropriate physical and chemical properties. Methanol, as well as ethanol, are immiscible with oil and form a heterogeneous two-phase system. The reaction proceeds at the interface, and intense stirring is necessary [53]. The heterogeneous system can be "removed" by the addition of another liquid (co-solvent), such as tetrahydrofuran, acetone, hexane [54], which forms one phase. The second most frequently used alcohol is ethanol, especially for homogeneous catalysts. Ethanol can be 
easy to produce from renewable sources, and transesterification usually processes at a lower temperature $\left(25-30^{\circ} \mathrm{C}\right)$ because, at a higher temperature, saponification is easily processed [55-57]. The higher number of carbons in the alcohol chain means lower reactivity but a higher boiling point-that is, under the same pressure, the transesterification could be carried out at higher temperatures. Ethanol forms azeotrope with water, and to gain pure ethanol without water is quite expensive. Simultaneously, increasing the carbon number slightly increases the caloric value of the esters [58,59].

Table 3. Properties of alcohols are the most often used for transesterification.

\begin{tabular}{cccccccc}
\hline Alcohols & $\begin{array}{c}\text { Number of } \\
\text { Carbons }\end{array}$ & $\begin{array}{c}\text { Boiling } \\
\text { Point, }^{\circ} \mathbf{C}\end{array}$ & $\begin{array}{c}\text { Miscible } \\
\text { with Oil }\end{array}$ & Reactive & Hygroscopic & Bio-Source & Price \\
\hline methanol & 1 & 65 & no & ++ & + & - & ++ \\
ethanol & 2 & 78 & no & + & - & ++ & + \\
butanol & 4 & 118 & yes & - & - & + \\
\hline
\end{tabular}

Note: sign + means positive for transesterification.

Butanol is hydrophobic, less corrosive, and miscible with oil, and the reaction occurs in the whole volume. Due to the higher boiling point (Table 3), a higher reaction temperature can be used, but the higher temperature supports saponification. Therefore, transesterification is carried out at lower temperatures $\left(25-30^{\circ} \mathrm{C}\right)[59,60]$. Butanol is possible to use as a co-solvent [61]. On the industrial scale, only methanol is used because it is the most active. The other alcohols are used only in a laboratory scale.

\subsection{The Types of Catalysis}

The transesterification can be conducted without a catalyst at high temperatures and pressures (alcohol in the supercritical stage [62]). Otherwise, it is necessary to use a catalyst $[63,64]$. Generally, the catalysis of transesterification can be either chemical or enzymatic. The chemical catalysts are classed as homogeneous or heterogeneous, which are further classed into an alkali or acid. The disadvantage of homogeneous catalysts is the possibility of being recovered from the reaction mixture and reused. The properties of each type of catalyst are shown in Table 4.

Table 4. Overview of the catalysts used in transesterification.

\begin{tabular}{|c|c|c|}
\hline Type of Catalyst & Advantages & Disadvantages \\
\hline Homogeneous alkali & $\begin{array}{ll}\text { - } & \text { mild reaction conditions } \\
\text { - } & \text { and less energy required } \\
\text { - } & \text { easy availability of catalyst } \\
\text { - } & \text { the high reaction rate (4000 times faster } \\
\text { than acid ones) } & \text { high yields of reaction }(99 \%)\end{array}$ & $\begin{array}{l}\text { - using only quality oils (if the FFA content } \\
\text { in the oil is more than } 2 \mathrm{wt} \% \text {, the } \\
\text { saponification occurs) } \\
\text { - } \quad \text { irreversible loss of catalyst and decreasing } \\
\text { of ester yield } \\
\text { - } \\
\text { produces more wastewater from } \\
\text { purification }\end{array}$ \\
\hline Heterogeneous alkali & $\begin{array}{ll}\text { - } & \text { environmentally friendly } \\
\text { - } & \text { reusable } \\
\text { - } & \text { easy to separate from the reaction mixture } \\
\text { the possibility of continuous production }\end{array}$ & $\begin{array}{l}\text { - } \quad \text { increases the energy requirements for the } \\
\text { reaction (temperature, pressure) } \\
\text { - } \quad \text { challenging catalyst synthesis } \\
\text { - } \quad \text { catalyst instability } \\
\text { lower activity in comparison with } \\
\text { homogeneous ones }\end{array}$ \\
\hline
\end{tabular}

insensitive to FFA and water content in the

oil

Homogeneous acid
- $\quad$ esterification and transesterification occur simultaneously

- $\quad$ easy availability of catalyst

- $\quad$ saponification can be avoided low reaction rate

can lead to equipment corrosion irreversible loss of catalyst 
Table 4. Cont.

\begin{tabular}{|c|c|c|}
\hline Type of Catalyst & Advantages & Disadvantages \\
\hline Heterogeneous acid & $\begin{array}{l}\text { - } \quad \text { insensitive to FFA and water content in the } \\
\text { oil } \\
\text { - } \quad \text { esterification and transesterification occur } \\
\text { simultaneously } \\
\text { - } \quad \text { recyclable }\end{array}$ & $\begin{array}{ll}- & \text { low reaction rate } \\
- & \text { high reaction conditions and longer } \\
\text { - } & \text { reaction times } \\
\text { - } & \text { higher energy requirement } \\
\text { catalyst instability }\end{array}$ \\
\hline Enzyme & $\begin{array}{ll}- & \text { mild reaction conditions } \\
\text { - } & \text { environmentally friendly and } \\
\text { non-polluting } \\
\text { - } \quad \text { reusable }\end{array}$ & $\begin{array}{ll}\text { - } & \text { very slow reaction rate } \\
\text { - } & \text { high cost } \\
\text { - } & \text { sensitive to alcohol (methanol can } \\
& \text { deactivate the enzyme) }\end{array}$ \\
\hline
\end{tabular}

Nowadays, enzymatic catalysis is getting a lot of attention [65]. Various types of lipases are used as a catalyst. Moreover, lipases are very often immobilized on different carriers. Their main advantages are a lower reaction temperature (usually $25-40{ }^{\circ} \mathrm{C}$ ), that is, lower energy consumption, and the immobilized enzyme can be reused. Enzyme catalysts are insensitive to the content of FFAs and water in the input oil, that is, there can be used oil with a high content of FFAs and water. Another great advantage is an easy recovery of glycerol from esters because the saponification reaction does not proceed. The enzymatic catalyst also has some limitations, such as the high cost of the enzyme, prolonged reaction time (up to $10 \mathrm{~h}$ ), low yield, and the possibility of the enzyme being deactivated by alcohol, especially methanol $[66,67]$. The enzymatic catalysts are not further discussed because this is not the aim of this paper.

\subsubsection{Homogeneous Catalysis}

The homogeneous catalysts for transesterification are strong alkaline or acid matters that are well-soluble with alcohol. The alkaline homogeneous catalysts are the most common because of their low cost and high efficiency [68]. The most popular are $\mathrm{NaOH}$ and $\mathrm{KOH}$ or their alcoholates (especially $\mathrm{NaOCH}_{3}$ ). They are the only ones used on an industrial scale [14].

In the case of alkaline catalysis, the reaction particle is the alcoholate of the corresponding metal formed by the dissolving of strong hydroxides in the alcohol (e.g., methanol and $\mathrm{KOH}$ (Equation (3)).

$$
\mathrm{CH}_{3} \mathrm{OH}+\mathrm{K}^{+} \mathrm{OH}^{-} \leftrightarrows \mathrm{CH}_{3} \mathrm{O}^{-} \mathrm{K}^{+}+\mathrm{H}_{2} \mathrm{O}
$$

This is an equilibrium reaction, and therefore it is suitable to use the feedstock with the lowest water content since water shifts the equilibrium towards alcohol and hydroxide, which leads to saponification. A simplified reaction scheme of alkali catalyzed transesterification (Figure 1A). Since transesterification is a reversible reaction, it is mostly conducted in excess alcohol to the stoichiometric amount (methanolysis $2 \times$, butanolysis $4 \times$ ). The microemulsion (caused by formed soaps) is formed throughout transesterification [69].

The usual use of alkaline catalyst is $0.9-1.2 \mathrm{wt} \%$ to oil [70], which depends on the type and composition of oil and the type of the catalyst. The low-quality triacylglycerols resources with a high content of FFAs (up to $3 \mathrm{wt} \%$ ) [71] and water [72] cannot be used for alkaline catalysts because the presence of water causes hydrolysis of oils to the FFAs [73]. The catalyst is lost (i) by neutralization of the FFAs contained in the oil (D) and (ii) by the side reaction: saponification of acylglycerols (B) or esters (C). Reactions are shown in Figure 1 , where $R_{i}$ is a chain of higher fatty acids.

During the removal of unreacted alcohol, a reverse reaction may occur (from the esters and glycerol, there are successively formed MG, DG, and TG), and therefore the reactions have to be finished [74] (the catalyst is not possible to reuse). The reaction can be finished by stopping the mixing and subsequent separation of the formed EP from the glycerol phase (GP), whereby the catalyst as a polar substance passes into the GP, and the 
reaction does not proceed further. The obtained EP is usually known as crude biodiesel, which contains many impurities, such as remaining acylglycerols, glycerol, FFAs, methanol, vegetable dyes, soaps, and salts. The glycerol phase is usually of low quality because it also contains (besides glycerol) many organic and inorganic impurities, such as water, soaps, esters, vegetable dyes, and remaining catalysts or products of catalyst neutralization. Both phases have to be purified, that is, further technological treatment is necessary, increasing biodiesel production's energy consumption. This approach is traditionally used in the industry [52].

$\mathbf{A}$

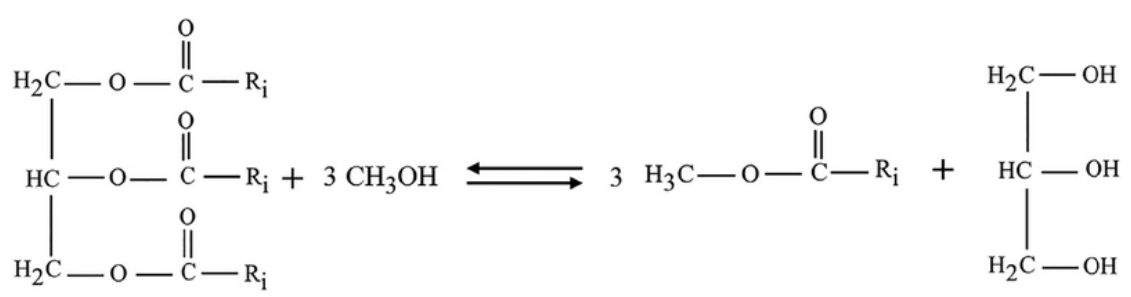

B

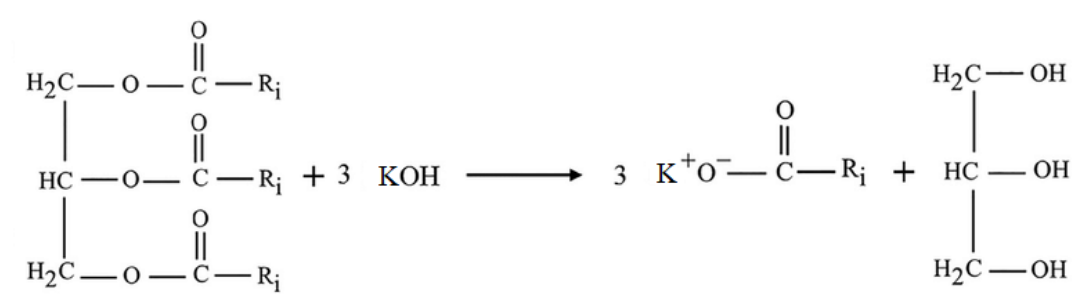

C

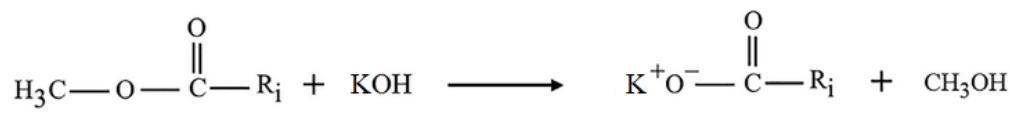

D

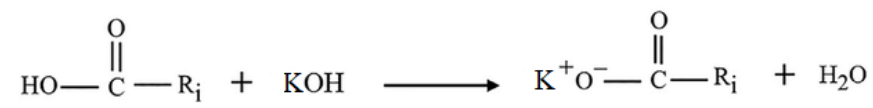

Figure 1. Simplified scheme of the chemical reaction process through alkali catalysed transesterification-transesterification (A), saponification of triacylglycerols (B), and esters (C), and neutralisation of FFA (D).

Another approach is to stop transesterification by neutralization of the catalyst because approximately $60 \%$ of the catalyst is unreacted [75]. The weak acid (e.g., gaseous $\mathrm{CO}_{2}$ ) or inorganic acids (e.g., $\mathrm{H}_{3} \mathrm{PO}_{4}$ and $\mathrm{HCl}$ ) can be used for neutralization. The carbon dioxide added into the reaction mixture has the advantage that it behaves as a weak acid and neutralizes only alkaline catalysts $(\mathrm{KOH})$, and cannot convert the formed soaps into FFAs, that is, it does not increase the acid number. Conversely, the amount of potassium ions and free glycerol in the EP is mostly higher than that allowed by the European standard EN 14214. Moreover, the separation of the EP from the GP usually takes longer than $24 \mathrm{~h}$. Therefore, after removing excess alcohol from the whole reaction mixture, it is possible to add a defined amount of water into the reaction mixture (determined according to the photometric titration [76]), which accelerates product separation and improves the properties of the EP. The added water as a polar substance passes into the GP and dilutes it, that is, it decreases the glycerol content in the GP [77].

The application of inorganic (strong) acids for transesterification stopping is usually for the kinetics study, that is, this procedure is not part of biodiesel production [78]. However, inorganic acids, such as $\mathrm{HCl}$ and $\mathrm{H}_{3} \mathrm{PO}_{4}$, are also possible to use for stopping. Two options for acid addition have been described: (i) addition into the whole reaction mixture until the $\mathrm{pH}$ falls to 2-3, which means that soaps are converted into FFAs (increases the acid number of the EP), and it is necessary to remove the formed FFAs from the EP [79], and 
(ii) precisely, only then are the catalytically active methoxide ions neutralized, the FFAs are not formed, and the acid number remains almost zero [80].

The homogeneous acid catalysts are a suitable alternative for transesterification with raw materials with a high content of FFAs, which are usually waste cooking oils. Moreover, the waste cooking oil usually contains other impurities, such as water and solid particles $[81,82]$ and is degraded by the thermal process, which causes lower oxidation stability and polymerization of oil. As homogenous acid catalysts are used, Brønsted acids can be sulphuric, sulfonic, hydrochloric, and so forth. [83-85].

Freedman et al. claimed that the use of acid catalysts is much more effective than the use of basic ones if the sources of triacylglycerols contain more than $1 \mathrm{wt} \%$ of FFAs [86]. The acid catalysts also have higher levels of resistance to other impurities in comparison with the basic ones. The mechanism of using acid catalysis in transesterification differs from the case of using an alkaline one. In the case of acid catalysis, the proton attacks the carboxylic oxygen group, and the subsequent steps are electron transfer and the release of glycerol from the ester. Therefore, acid catalysts are suitable for oils with a high content of FFAs, as they can simultaneously transesterify oils and esterify the FFAs, but their reaction rates are slow. Acid catalysts are almost 4000 times slower than alkaline catalysts. The use of acid catalysts provides a high yield of esters because the saponification reaction does not occur, but requires a high temperature (usually above $100^{\circ} \mathrm{C}$ ) and high molar ratio of alcohol/oil (more than 6:1 alcohol/oil) and longer reaction time (3-48 h) in comparison with the alkaline ones. $[87,88]$. The residues of acid catalysts are necessary to eliminate the esters because they can attack the metallic parts of the engine and cause corrosion. The molar ratio of alcohol/oil is an important factor that significantly influences the transesterification performance. An increasing excess of alcohol supports the formation of products, but conversely, the increasing excess of alcohol makes the separation of glycerol difficult. Therefore, it is necessary to establish an optimal molar ratio of alcohol/oil for each acid catalyst according to the optimization of experiments.

Due to the reaction rate limitation, a two-step reaction is used, where firstly the FFAs are esterified, and subsequently, transesterification is carried out with an alkaline catalyst. This approach could provide a high biodiesel conversion (up to 98\%) [40].

\subsubsection{Heterogeneous Catalysis}

Heterogeneous catalysts can solve the problems with the separation of catalysts and their reuse. The heterogeneous catalysts are solid matters (dissoluble in alcohols) with alkaline $[89,90]$ or acid properties, which can be in the form of powders, monoliths or supported on some material. It can be impregnated materials, metallic oxides (alkaline earth metals, transition metals) [91], various types of mixed oxides (Ca-Al, $\mathrm{Mg}-\mathrm{Al}, \mathrm{Mg}-\mathrm{Fe}$, etc.) [92-95], supported metal oxides [96], $\mathrm{CaO}$ from food waste [97,98], NaX zeolites, heteropolyacid, coated $\mathrm{ZnO}$, a biomass-derived catalyst [99], and so forth. (Table 5).

These catalysts are considered environmentally friendly due to decreasing water usage during the separation of esters from glycerol and especially ester purification, because they are easy to recover from the reaction mixture. Another indisputable advantage is their reusability, which could make biodiesel production a continuous process [100]. The main disadvantage of the heterogeneous catalyst is lower activity than the homogeneous one because the reaction proceeds only on the active centres. This is the reason that the transesterification usually proceeds at (i) a higher molar ratio of alcohol to oil, (ii) a higher catalyst amount, and (iii) a higher temperature than the boiling temperature of alcohol at atmospheric pressure (the pressure reactor is necessary). These are the main reasons for not using a heterogeneous catalyst on an industrial scale. Moreover, the synthesis of the catalyst can be quite difficult and time-consuming. An important parameter is also the high stability of the catalyst, that is, almost no leaching of metals into the reaction products is necessary [101,102]. 
Table 5. The list of heterogeneous catalysts used in transesterification.

\begin{tabular}{|c|c|c|c|c|}
\hline Type of Catalyst & Feedstock (Oil/Alcohol) & $\begin{array}{c}\text { Operating Conditions } \\
\text { (Temp./Amount of Catalyst/Molar Ratio } \\
\text { Alcohol to Oil) }\end{array}$ & Yield, \% & Ref. \\
\hline La-Ca/halloysite & palm oil/MeOH & $150{ }^{\circ} \mathrm{C} / 7 \mathrm{wt} \% / 18: 1$ & 97.5 & [103] \\
\hline quicklime & mustard seed oil/MeOH & $60^{\circ} \mathrm{C} / 9.8 w t \% / 6.1: 1$ & 96.5 & [104] \\
\hline kettle limescale & $\mathrm{UCO} / \mathrm{MeOH}$ & $60^{\circ} \mathrm{C} / 14 \mathrm{wt}^{\circ} \% / 2.15: 5(v / v)$ & 97.2 & [105] \\
\hline GO5.0Al(HSP) & sunflower oil/MeOH & $120{ }^{\circ} \mathrm{C} / 1 \mathrm{wt} \% / 30: 1$ & 97 & [106] \\
\hline $\mathrm{Fe} / \mathrm{Ba} / \mathrm{Al}_{2} \mathrm{O}_{3}$ & $\mathrm{UCO} / \mathrm{MeOH}$ & $65^{\circ} \mathrm{C} / 6 \mathrm{wt} \% / 18: 1(w \mathrm{t} / \mathrm{wt})$ & 84.2 & [107] \\
\hline $\mathrm{Ce} /$ dolomite & palm oil/MeOH & $65^{\circ} \mathrm{C} / 0.05 w \mathrm{t} \% / 15$ & 97.2 & [108] \\
\hline $\mathrm{CaO} /$ wollastonite & palm oil/MeOH & $65^{\circ} \mathrm{C} / 8 w \mathrm{wt} \% / 15: 1$ & 97.6 & [109] \\
\hline $\mathrm{Mg} /$ clinoptilolite & $\mathrm{UCO} / \mathrm{MeOH}$ & $70^{\circ} \mathrm{C} / 4 \mathrm{wt} \% / 16: 1$ & 98.7 & [110] \\
\hline $\mathrm{K} /$ kaolinite & $\mathrm{UCO} / \mathrm{MeOH}$ & $70{ }^{\circ} \mathrm{C} / 15 \mathrm{wt} \% / 14: 1$ & 94.8 & [111] \\
\hline $\mathrm{Zn} / \mathrm{CaO}$ & $\mathrm{UCO} / \mathrm{MeOH}$ & $65^{\circ} \mathrm{C} / 5 \mathrm{wt} \% / 20: 1$ & 96.7 & [112] \\
\hline $\mathrm{Al}_{2} \mathrm{O}_{3} / \mathrm{Fe}_{3} \mathrm{O}_{4}$ & $\mathrm{UCO} / \mathrm{MeOH}$ & $100{ }^{\circ} \mathrm{C} / 5 \mathrm{wt} \% / 30: 1$ & 77 & [113] \\
\hline $\mathrm{S}-\mathrm{La}_{2} \mathrm{O}_{3} / \mathrm{NaY}$ & castor oil/EtOH & $70{ }^{\circ} \mathrm{C} / 10 w \mathrm{w} \% / 15.1: 1$ & 84.6 & [114] \\
\hline $\mathrm{TiO}_{2}-\mathrm{CaO}$ & palm oil/MeOH & $65^{\circ} \mathrm{C} / 0.5 \mathrm{wt} \% / 5: 3$ & 95 & [115] \\
\hline $\mathrm{MgO}-\mathrm{Al}_{2} \mathrm{O}_{3}$ & castor oil/BuOH & $80^{\circ} \mathrm{C} / 5 \mathrm{wt} \% / 6: 1$ & 97 & [116] \\
\hline $\mathrm{Cu} / \mathrm{Zn} / \mathrm{Al}_{2} \mathrm{O}_{3}$ & $\mathrm{UCO} / \mathrm{MeOH}$ & $65^{\circ} \mathrm{C} / 10 \mathrm{wt} \% / 20: 1$ & 89.5 & [117] \\
\hline sulfonated active carbon & soybean oil/EtOH & $75{ }^{\circ} \mathrm{C} / 20 w t \% / 6: 1$ & 88.7 & [118] \\
\hline modified graphene & $\mathrm{RSO} / \mathrm{MeOH}$ & $130^{\circ} \mathrm{C} / 1 \mathrm{wt} \% / 12: 1$ & 80 & [119] \\
\hline Ca-Al mixed oxide & $\mathrm{RSO} / \mathrm{MeOH}$ & $65^{\circ} \mathrm{C} / 4 w \mathrm{wt} \% / 24: 1$ & 90 & [92] \\
\hline Mg-Fe mixed oxide & $\mathrm{RSO} / \mathrm{MeOH}$ & $117^{\circ} \mathrm{C} / 4 \mathrm{wt} \% / 24: 1$ & 70 & [120] \\
\hline Mg-Al mixed oxide & $\mathrm{RSO} / \mathrm{MeOH}$ & $117^{\circ} \mathrm{C} / 4 w t \% / 24: 1$ & 75 & [121] \\
\hline
\end{tabular}

One of the possible methods of catalyst synthesis is the impregnation of various alkali materials to the convenient support, such as $\mathrm{Al}_{2} \mathrm{O}_{3}, \mathrm{TiO}_{2}, \mathrm{MgO}$, and so forth, with the aim of increasing the number of basic sites. Sulaiman et al. studied the influence of various concentrations of $\mathrm{Ba}, \mathrm{Ca}, \mathrm{Mg}$, $\mathrm{Sr}$, and $\mathrm{Fe}$ oxides impregnated on $\mathrm{Al}_{2} \mathrm{O}_{3}$ on the activity of catalysts in the transesterification of refined UCO (used cooking oil) with methanol. The type of active species affected the specific surface area and basicity of the catalyst. The activity positively correlated with the basicity; the highest level of activity was achieved for $\mathrm{BaFe} / \mathrm{Al}_{2} \mathrm{O}_{3}\left(0.4 \mathrm{wt} \%\right.$ of $\mathrm{Fe}$ and $1.4 \mathrm{wt} \%$ of Ba) calcined at $800{ }^{\circ} \mathrm{C}$ [107]. Abukhadra et al. used the zeolite (clinoptilolite) as the support, which is characterized by the high specific surface area. The impregnated alkali metals, such as $\mathrm{Na}, \mathrm{K}, \mathrm{Mg}$, and $\mathrm{Ca}$ increased the basic properties. The significant differences in the ester yield (UCO with methanol was used) for different metals were not observed. The reusability was tested for $\mathrm{Mg}$ /clinoptilolite for five cycles: the ester yield only insignificantly decreased from 98.4 to $94.5 \%$ [110]. The potassium impregnated on kaolinite was studied: the presence of potassium positively affected the yield of the ester until $30 \mathrm{wt} \%$ (potassium in kaolinite), where $94.8 \%$ of the ester yield after $3 \mathrm{~h}$ was achieved. A higher amount did not significantly affect the transesterification. If the concentration of potassium was $40 \mathrm{wt} \%$, a slight drop of ester yield was observed, which was explained by the decreasing of basicity (the partial exchange of Al-O-H group for Al-O-K groups). The reusability was tested; the decreasing of ester yield was from $94.8 \%$ in the first cycle to $83.3 \%$ in the fifth cycle due to potassium leaching [111].

The impregnation of $\mathrm{Al}_{2} \mathrm{O}_{3}$ by $\mathrm{MgO}$ increased the basicity and surface area of the catalyst. The transesterification of castor oil with butanol was carried out at $80^{\circ} \mathrm{C}$ with a $6: 1$ butanol-to-oil molar ratio and $5 \mathrm{wt} \%$ of the catalyst with a yield $97 \%$ after $6 \mathrm{~h} \mathrm{[116].}$ The $\mathrm{Al}_{2} \mathrm{O}_{3}$ as the support of $\mathrm{CuNO}_{3}$ and $\mathrm{ZnNO}_{3}$ was used for the preparation of the catalyst for transesterification of UCO with methanol. The highest basicity was observed for $\mathrm{Cu} / \mathrm{Zn} / \mathrm{Al}_{2} \mathrm{O}_{3}$ catalysts with $2.8 \mathrm{wt} \%$ of $\mathrm{Cu}$ and $7.1 \mathrm{wt} \%$ of $\mathrm{Zn}$ calcined at $800{ }^{\circ} \mathrm{C}$. The transesterification was carried out at $65{ }^{\circ} \mathrm{C}$, a $20: 1$ molar ratio of methanol to oil, and 10 $\mathrm{wt} \%$ of a catalyst with the highest ester yield of $89.5 \%$ after $2 \mathrm{~h}$. The yield slightly reduced to $83.3 \%$ after five cycles [117]. As the support, the hierarchical microspheres $\gamma-\mathrm{Al}_{2} \mathrm{O}_{3}$ were prepared. The reason was to increase the pore size because the triacylglycerides 
comprise quite large molecules (which reduces the inter-diffusion). The support was impregnated by graphene oxide for increasing the acid-based properties. The impregnation of $5 \mathrm{wt} \%$ of graphene oxide significantly increased the basicity to $12.3 \mathrm{mmol} \mathrm{g}^{-1}$ (without $0.4 \mathrm{mmol} \mathrm{g}^{-1}$ ). On the other hand, the acidity decreased from 5.6 to $1.7 \mathrm{mmol} \mathrm{g}^{-1}$. The catalyst was tested in transesterification of fresh and used sunflower oil with methanol. The stability was influenced by the larger amount of free fatty acids in the oil. After six cycles, the conversion decreased from 97 to $95 \%$ for fresh, and from 93 to $81 \%$ for used oil [106].

Calcium oxide, which is a widely studied metal as the basic catalyst, can be (i) impregnated on some support or (ii) used as bulk. The $\mathrm{CaO}$ impregnated on wollastonite (calcium inosilicate) and calcined at $750{ }^{\circ} \mathrm{C}$ was studied in transesterification of palm oil with methanol. The stability was studied by catalyst reusing: the ester yield decreased from 97.6 to $87.3 \%$ (after $3 \mathrm{~h}$ ) observed for one and five cycles [109]. Borah et al. studied the $\mathrm{CaO}$ impregnated with $\mathrm{Zn}(1 \mathrm{wt} \%)$ in the transesterification of UCO with methanol. The transesterification with $1 \mathrm{wt} \%$ of $\mathrm{Zn}$ on $\mathrm{CaO}$ catalyst was carried out at $65{ }^{\circ} \mathrm{C}, 5 \mathrm{wt} \%$ of the catalyst, and 20:1 molar ratio of methanol/oil, and we observed a $96.7 \%$ ester yield after $4 \mathrm{~h}$. The ester yield significantly decreased to $64.4 \%$ after five cycles, which was caused by zinc leaching. Unfortunately, the authors did not analyze the content of $\mathrm{Ca}$ and $\mathrm{Zn}$ in the reaction mixture [112]. The $\mathrm{TiO}_{2}-\mathrm{CaO}$ catalyst prepared by the impregnation method showed good catalytic performance in the transesterification of palm oil with methanol under UV radiation. The $\mathrm{TiO}_{2}$ promoted the catalytic activity due to eased cation generation from $\mathrm{CaO}$, which were easily inserted into vacant sites on the surface of $\mathrm{TiO}_{2}$. The highest ester yield (95\%) was observed at $65{ }^{\circ} \mathrm{C}$ with only $0.5 \mathrm{wt} \%$ of the catalyst and $5: 3$ methanol-to-oil molar ratio after $150 \mathrm{~min}$. However, the ester yield was decreased for five cycles, where the ester yield was only $60 \%$ [115]. The halloysite nanotube functionalized by $\mathrm{La}-\mathrm{Ca}$ bimetallic oxide with a 1.5 molar ratio of $\mathrm{La}_{2} \mathrm{O}_{3} / \mathrm{CaO}$ showed good catalytic properties in the transesterification of palm oil with methanol because the lanthanum promoted the methanol adsorption, which increased activity. The yield of ME was $97 \%$ after two hours at $150{ }^{\circ} \mathrm{C}$ with $7 \mathrm{wt} \%$ of catalyst. [103]. The bulk CaO calcined at $500{ }^{\circ} \mathrm{C}$ was used as the catalyst in the transesterification of white mustard seed oil with methanol. The ester yield of $96.5 \%$ was reached for $9.8 \mathrm{wt} \%$ of catalyst and molar ratio of methanol to oil between 6.1 to $11.6: 1$ after $50 \mathrm{~min}$ [104]. The kettle limescale $\left(\mathrm{CaCO}_{3}\right)$ calcined at $900{ }^{\circ} \mathrm{C}$ was used as a source of $\mathrm{CaO}$. The reaction was carried out with co-solvent (acetone) and various reaction conditions. The highest yield (97.2\%) was observed at $60{ }^{\circ} \mathrm{C}, 14.0 \mathrm{wt} \%$ of catalyst, and 2:15:5 volume ratio methanol to oil. The calcium was leached during the transesterification, which caused catalyst deactivation and the formation of calcium soaps [105].

Niu et al. studied the effect of cerium on the activity and stability of the catalysts prepared from dolomite calcined at $800{ }^{\circ} \mathrm{C}$. The $\mathrm{CaO}$ and $\mathrm{MgO}$ were formed after calcination, and cerium (0.6 wt $\%$ ) was wet-impregnated. Good stability was observed in the transesterification of palm oil with methanol during five cycles, where the ester yield decreased from 97.2 to $88.6 \%$ ( 2 h transesterification). The reusability was compared with oxides without cerium, where the ester yield decreased from 95.1 to $83.5 \%$. The increase of the catalyst stability was explained by the synergistic effect between $\mathrm{CaO}$ and formed $\mathrm{CeO}_{2}$ [108].

The mixed oxides (most often synthesized by calcination from hydrotalcites of various metals, such as $\mathrm{Ca}, \mathrm{Mg}, \mathrm{Al}, \mathrm{Fe}$, and $\mathrm{Zn}$ usually synthesized by co-precipitation) are other possible catalysts. The Ca-Al mixed oxides showed good catalytic activity in the transesterification of RSO oil with methanol (at $65^{\circ} \mathrm{C}, 24: 1$ molar ratio of methanol to oil and $4 \mathrm{wt} \%$ of catalyst). It was found that the Ca-Al mixed oxides are stable in ester, oil, and methanol. However, the additional phase $\mathrm{CaO}$, founded in $\mathrm{Ca}-\mathrm{Al}$ mixed oxides, was soluble in the water present in the feedstock. Therefore, the $\mathrm{CaO}$ caused the instability of the catalyst [121]. Other types of mixed oxides are $\mathrm{Mg}-\mathrm{Al} / \mathrm{Fe}$, which were also tested in the transesterification of RSO oil with methanol. The molar ratio $\mathrm{Mg}$ to $\mathrm{Al}$ influenced the 
catalyst properties: the basicity was decreasing, but the specific surface area, as well as ester yield, were increasing with $\mathrm{Mg} / \mathrm{Al}$ molar ratio. The highest ester yield (75\%) was observed for $\mathrm{Mg} / \mathrm{Al}$ molar ratio 7.2 (at $117^{\circ} \mathrm{C}, 24: 1$ molar ratio of methanol/oil, $4 \mathrm{wt} \%$ of the catalyst after $8 \mathrm{~h}$ ) [121]. On the other hand, the highest ester yield (70\%) was observed for $\mathrm{Mg}-\mathrm{Fe}$ mixed oxides with a $\mathrm{Mg} / \mathrm{Fe}$ molar ratio of $6: 1$ under the same reaction conditions [120]. The $\mathrm{Mg}-\mathrm{Al}$ and $\mathrm{Mg}-\mathrm{Fe}$ mixed oxides were stable because the concentration of $\mathrm{Mg}, \mathrm{Al}$, and Fe in the products was negligible.

The basic catalyst, zeolites and mixed with surfactants and kaolin were studied in the transesterification of castor oil with ethanol. The specific surface area decreased with the increase of the calcination temperature $\left(600-1000{ }^{\circ} \mathrm{C}\right)$ from 369 to $2 \mathrm{~m}^{2} \mathrm{~g}^{-1}$. The addition of surfactant slightly increased the specific surface area and basicity. The basicity decreased with the increase of the calcination temperature from 12.7 to $7.5 \mathrm{mmol} \mathrm{g}^{-1}$. The optimized reaction conditions were determined: $70{ }^{\circ} \mathrm{C}, 15: 1$ molar ratio ethanol/oil and $10 \mathrm{wt} \%$ of catalyst to oil, where the ester yield was $84.6 \%$ after $50 \mathrm{~min}$. Moreover, the decrease to $75 \%$ of the ester yield was presented after five cycles [114].

The heterogeneous acid catalysts were developed for (trans)esterification of oil with a high content of FFA (usually contained in the used UCO). The magnetic catalysts $\mathrm{Al}_{2} \mathrm{O}_{3} / \mathrm{Fe}_{3} \mathrm{O}_{4}$ with a mass ratio of oxides 0.5 were prepared by incorporation of $\mathrm{Al}_{2} \mathrm{O}_{3}$ on the $\mathrm{Fe}_{3} \mathrm{O}_{4}$ nanoparticles. A strong acid was mainly present in the catalysts. The catalysts were tested in the transesterification of UCO with methanol, and the $77 \%$ ester yield after $2 \mathrm{~h}$ was observed [113]. Another type of catalyst is the sulfonated active carbon prepared by impregnation of active carbon by 4-benzenediazoniumsulfonate. The catalyst was used in the transesterification of soybean oil with ethanol $\left(75^{\circ} \mathrm{C}, 6: 1\right.$ molar ratio ethanol to oil and $20 \mathrm{wt} \%$ to catalyst). The reaction mixture was stirred by a microwave for better mass transfer. The highest ester yield $(88.7 \%)$ was observed after $20 \mathrm{~min}$ [118]. The modified graphene by diazonium cation showed suitable catalytic activity in the transesterification of rapeseed oil with methanol. Although the catalyst had a lower concentration of acid sites $\left(1.46 \mathrm{mmol} \mathrm{g}^{-1}\right)$, it showed the best catalytic activity, which was explained by the formation of a unique two-dimensional sheet structure with good dispersion of $-\mathrm{SO}_{3} \mathrm{H}$ groups. The $80 \%$ ester yield $\left(130{ }^{\circ} \mathrm{C}, 12: 1\right.$ molar ratio methanol/oil, and $1 \mathrm{wt} \%$ of catalyst to oil after $24 \mathrm{~h}$ ) was determined. However, the ester yield was only $60 \%$ after four cycles [119].

\subsection{The Separation and Purification}

The separation of the final product from other matter and its purification is an essential part of biodiesel production. After transesterification, the first step is separating the ester phase from the glycerol phase by gravity field or using centrifugation, which is the most popular method in the industry [3]. These phases have different polarity and density-the EP (containing nonpolar ester) has a lower density than GP, which contains especially polar matters. However, the separation is not completed, and some glycerol remains in the EP (known as free glycerol), and some esters remain in the GP (ester losses). Moreover, the ester content in the GP depends on the type of oil [122] and alcohol used: in the range 6-15 wt\% for methanol [123] and in the range 13-29 wt\% for ethanol [124]. The ester content in the GP corresponds to ester loss during transesterification and decreases the methyl esters yield [125].

The glycerol phase is an integral part of biodiesel production and is mainly neglected and not further analysed because it is considered a waste product of transesterification. The exact composition of the GP generally depends on the transesterification process and on the method of separation and purification of the obtained esters. The GP usually contains 30-60 wt\% of glycerol and other kinds of matter: soaps, water, salts, alcohol, glycerides, remaining catalyst, and esters [126]. The GP can be treated by the addition of acids, which neutralise the alkali matter [127]. The formed glycerol is used in many areas of the industry [128,129].

The quality of fatty acid methyl esters has to conform to the values given by the European standard EN 14214. The standard specifies a total of 23 different parameters, 
for example, density, viscosity, flash point, acid number (free fatty acids content-FFAs), methanol content, water content, the content of reaction components: free glycerol (the content of pure glycerol in the ester phase-EP), MG, DG, TG, the content of group I metals $(\mathrm{Na}, \mathrm{K})$, group II metals $(\mathrm{Ca}, \mathrm{Mg})$, phosphorus content, and so forth, which as the final product have to conform and are necessary to determine. The standard methods for analysing parameters are recommended [130].

\section{The Green Diesel Production-Co-Processing}

Another process for the transformation of oils/fats to biofuels is the catalytic hydrotreating of triacylglycerols at high temperatures $\left(300-400^{\circ} \mathrm{C}\right)$ and pressure $(5.0-7.0 \mathrm{MPa})$. The formed biofuel, known as Green diesel or hydrotreated vegetable oil (HVO), is composed mainly of paraffins ( $\mathrm{n}$ - and iso-paraffins) in the range of 15-18 carbon atoms and is free of aromatics, oxygen, sulphur, nitrogen, or metals [34]. In terms of volume production processes, the hydrotreatment of vegetable and animal oils to paraffins (in diesel or jet fuel range) is considered as one of those with higher current commercial capacity, behind the biorefineries focused on the fermentation of sugars and starches to ethanol and the transesterification of vegetable and animal fats to FAME. In this way, some of the most representative companies of the sector have developed commercial triglycerides, FFA and tall oil hydroprocessing installations with a capacity value higher than 70,000 BPD during recent years (Figure 2). This fact is especially noticeable in the case of the Neste company with NExBTL technology for green diesel as the main product [131].

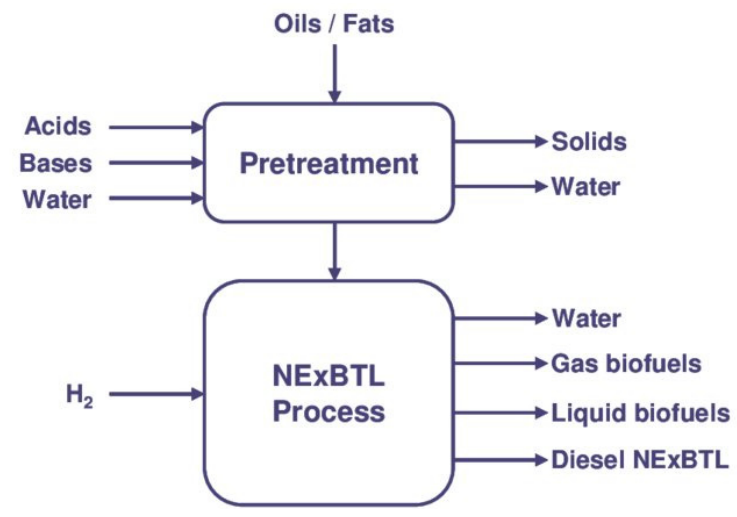

Figure 2. NExBTL catalytic hydrotreating of oils/fats technology for biodiesel production (Neste ${ }^{\circledR}$ 2021) [132].

The co-processing of middle distillates (e.g., straight-run gas oil) with vegetable oils (rapeseed oil, sunflower oil or even waste cooking oils) seems to be the most promising way to produce $\mathrm{HVO}$ on an industrial scale. In this way, the co-processing approach allows using the infrastructure already available in the existing refineries [133], that is, hydrotreating units, commonly used for sulphur compound elimination (among others) from diesel fractions. Moreover, using waste oils (using cooking oils or animal fats) also offers an efficient way of managing residues [134], obtaining a valuable biofuel integrated with the petroleum fraction [135].

Several studies have already been published relating to the co-processing of different crude oil feedstocks (heavy gas oil, vacuum gas oil, and atmospheric gas oil) with vegetable oils (including using cooking oil and animal fats) [136-138]. These works have shown the viability of the co-processing approach. A percentage of 5-10 $\mathrm{wt} \%$ looked to be optimal to not affect the regular activity of the hydrotreating units in terms of hydrogen consumption and catalyst deactivation. Figure 3 shows a schematic representation of the co-processing of triacylglycerols at current refinery hydrotreating units, taking into account the main products obtained during the process. 


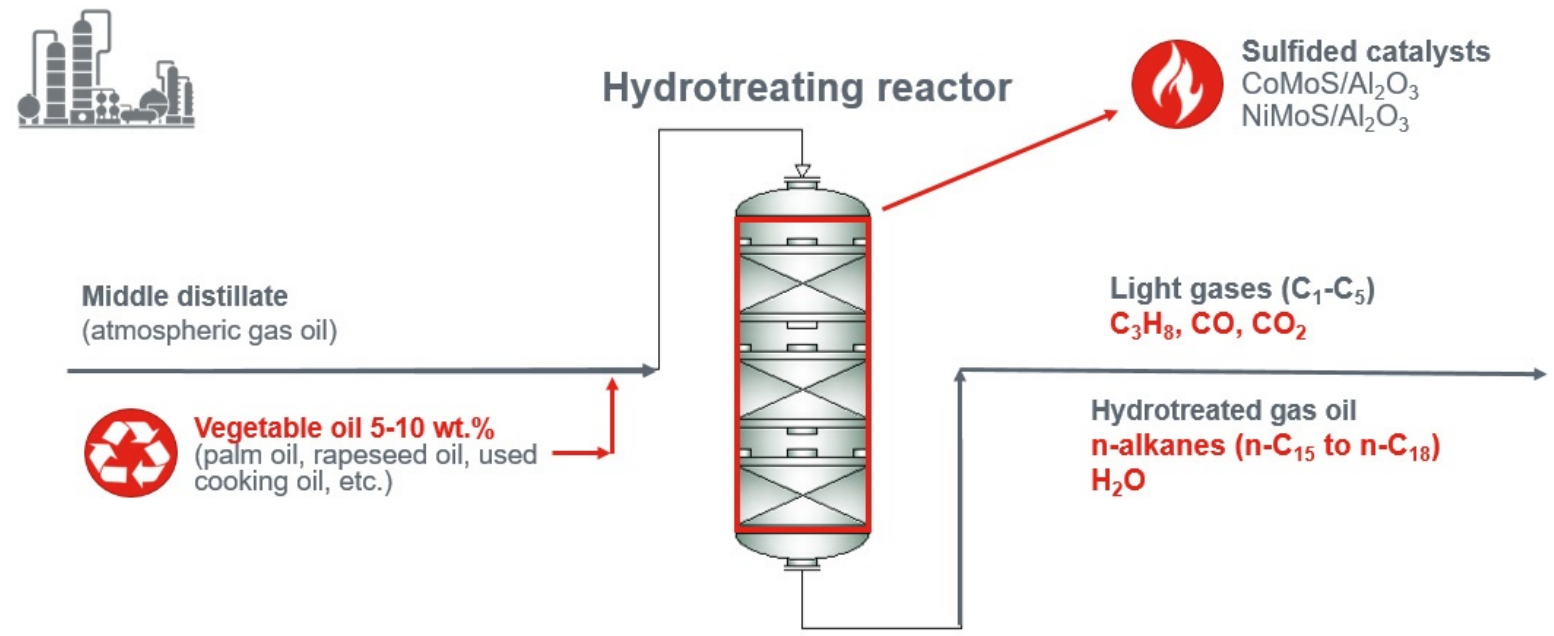

Figure 3. Co-processing of vegetable oils in hydrotreating units of current refineries.

\subsection{Reaction Pathways of Triacylglycerols Hydrotreating}

During co-processing, hydrodesulfurization (HDS) and hydrodenitrogenation (HDN) of the middle distillate occurs, as well as catalytic deoxygenation of the triacylglycerols of the vegetable oil. Figure 4 shows a scheme of the chemical reactions that occurred during triacylglycerol deoxygenation. In this way, the hydrogenation of double bonds of the alkyl chains is the first step. After this step, the hydrogenated molecule is broken, producing three free carboxylic acids and one $\mathrm{C}_{3} \mathrm{H}_{8}$ molecule. Then, the reaction continues via three possible pathways $[139,140]$ : hydrodeoxygenation (HDO), producing paraffins with an even number of carbon atoms (usually $\mathrm{nC}_{16}$ or $\mathrm{nC}_{18}$ ) and two molecules of water; and (hydro)decarboxylation (HDC), producing paraffins with an odd number of carbons $\left(\mathrm{nC}_{15}\right.$ and $\left.\mathrm{nC}_{17}\right)$ and one molecule of $\mathrm{CO}_{2}$ and (hydro)decarbonylation, leading paraffins with an odd number of carbons as well, but with one molecule of $\mathrm{H}_{2} \mathrm{O}$ and $\mathrm{CO}$ as side products. In the presence of $\mathrm{H}_{2}$, the gaseous side products $\left(\mathrm{CO} / \mathrm{CO}_{2}\right)$ could react to $\mathrm{CH}_{4}$ by methanation.

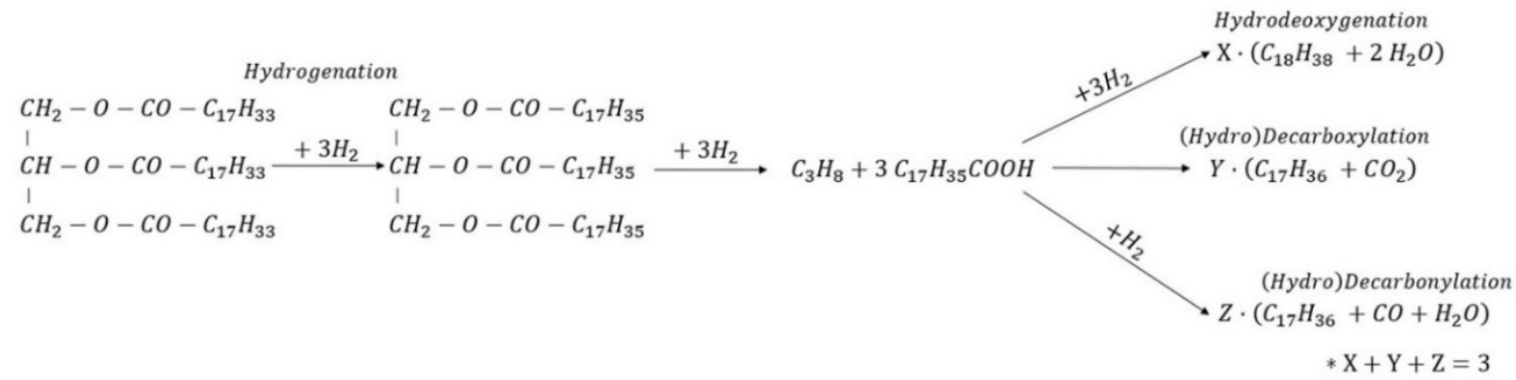

Figure 4. Reaction pathways in the hydrotreatment of triacylglycerol (triolein).

It is possible to estimate the catalyst selectivity between these deoxygenation pathways, using Equations (4) and (5) [141]:

$$
\begin{gathered}
\text { HDO }[\%]=\frac{\Delta(\text { even paraffins })}{\Delta(\text { total paraffins }[\text { even }+ \text { odd }])} \cdot 100 \\
\text { HDC } / \text { HDCn }[\%]=\frac{\Delta(\text { odd paraffins })}{\Delta(\text { total paraffins }[\text { even }+ \text { odd }])} \cdot 100
\end{gathered}
$$

where ' $\Delta$ (even paraffins)' and ' $\Delta$ (odd paraffins)' represent the paraffins produced from triacylglycerol hydrotreatment that formed according to HDO and HDC/HDCn pathways $(\mathrm{wt} \%)$, respectively, and ' $\Delta$ (total paraffins [even + odd])' represents the total paraffins formed only by the hydrotreatment of triglycerides ( $\mathrm{wt} \%$ ) (usually in the $\mathrm{nC}_{15}$ to $\mathrm{nC}_{20}$ range). 
As a result of co-processing, the hydrotreated gas oil increases its paraffin content, which means a higher content of diesel compounds in the product. This co-processing affects some hydrotreated gas oil parameters, such as density, flammability, cetane index, or cold flow properties [142]. The observed effect is significantly positive in density, cetane index, and flammability, obtaining a hydrotreated gasoil with lower density and better ignition quality. On the other hand, increasing the paraffin content could negatively affect the cold flow properties, such as pour point, cold filter plugging point, or cloud point. This effect has been already described in the literature [143]. It is significant in the case of co-processing that more than $10 \mathrm{wt} \%$ of triglycerides are in the feedstock. At this point, it would be necessary to add additives to control those parameters in the final product or blend with other desulfurized gasoil to attenuate the paraffin increase. There are not many significant studies studying this fact in detail.

\subsection{Hydrogen Consumption Due to Triacylglycerols Co-Processing}

As long as vegetable oil hydroprocessing or co-processing have been conceived to perform at similar conditions as middle distillate hydrotreating, an excess of hydrogen is required for the reaction. In this sense, a laboratory or pilot plant scale is commonly used with $\mathrm{H}_{2}$ with 99.99 vol.\% purity from commercial cylinders. However, it is common to use rich hydrogen flows produced in other units, such as platforming or naphtha refining at an industrial scale. These flows are composed of a high amount of $\mathrm{H}_{2}$ (around $80-90 \mathrm{wt} \%$ ), followed by other light gases, such as $\mathrm{CH}_{4}$ and $\mathrm{C}_{3} \mathrm{H}_{8}$.

In terms of $\mathrm{H}_{2}$ consumption, the $\mathrm{HDC} / \mathrm{HDCn}$ reactions are more efficient, with 6-9 molecules of $\mathrm{H}_{2}$ instead of 12 per triacylglyceride molecule being deoxygenated. However, as a reaction intermediate, the $\mathrm{CO}_{\mathrm{x}}$ derived from these reactions continues reacting in the presence of $\mathrm{H}_{2}$, affecting the catalytic activity. This by-product might increase the $\mathrm{H}_{2}$ consumed by side-reactions, such as methanation or reverse water gas shift reaction.

In general, the presence of other gases does not represent a significant problem during $\mathrm{HVO}$ production. Nevertheless, there is an exception with $\mathrm{CO} / \mathrm{CO}_{2}$ gases produced during the triacylglycerols deoxygenation reactions, in which those are the main products from the HDC/HDCn reactions. In this case, depending on the used catalysts, an inhibition effect of $\mathrm{CO} / \mathrm{CO}_{2}$ has been reported $[144,145]$ due to a decrease of $\mathrm{H}_{2}$ partial pressure and absorption phenomena of $\mathrm{CO}$ on active sites on CoMo catalysts, affecting the hydrotreating activity. Conventional NiMo hydrotreating catalysts look to be more efficient in the top layers of the industrial catalyst bed of industrial hydrotreating units [146].

Except in cases where the gas used for hydrotreating is recirculated, these named effects of $\mathrm{CO} / \mathrm{CO}_{2}$ absorption are not so significant. Hydrogen consumption due to triacylglycerols co-processing is a parameter to consider. It works as a limit to determine the maximum amount of vegetable oil/animal fat possible to proceed, or the proper operating conditions to carry out.

In terms of $\mathrm{H}_{2}$ consumption, recent works study the hydrotreating of triacylglycerols into n-alkanes using alternative $\mathrm{H}_{2}$ sources, such as oxalic acid, or under low hydrogen pressure [147]. These studies point to the significant hydrotreating activity of vegetable oils by commercial NiW and NiMo catalysts.

\subsection{Suitable Catalysts for Triacylglycerols Co-Processing}

Commercial sulfide transition metal-based catalysts, commonly used for hydrotreating, can also be used for co-processing [139]. These catalysts use molybdenum or wolfram as an active phase, promoted by nickel or cobalt in an $\mathrm{Al}_{2} \mathrm{O}_{3} / \mathrm{SiO}_{2}$ support. The metal composition of the catalysts depends on the reactions which we are interested to promote. In this way, Co-Mo catalysts were mainly used when a high HDS efficiency is required and $\mathrm{Ni}$-Mo ones when HDN efficiency is needed. On the other hand, W-based catalysts were chosen to promote hydrocracking reactions. The list of catalysts is in Table 6.

One of the most important parameters affected during co-processing was the hydrotreating effectiveness (i.e., HDS and HDN efficiencies Equations (6) and (7)) 


$$
\begin{aligned}
& \operatorname{HDS}(\%)=\frac{\left(S_{0}-\left(S_{\mathrm{p}} \cdot \eta\right)\right)}{S_{0}} \cdot 100 \\
& \operatorname{HDN}(\%)=\frac{\left(N_{0}-\left(N_{\mathrm{p}} \cdot \eta\right)\right)}{N_{0}} \cdot 100
\end{aligned}
$$

where $S / N_{0}$ and $S / N_{p}$ represent the sulphur or nitrogen content of the feedstock and the liquid product, respectively ( $\mathrm{wt}, \mathrm{ppm}$ ), and ' $\mathrm{n}$ ' represents the process yield: the mass ratio between the desulfurized gasoil obtained and the liquid feedstock.

The addition of triacylglycerols to the feedstock during co-processing affects the catalyst activity, that is, hydrotreating efficiency, either to increase heteroatoms to remove from the feed [148] or for the effect of side products [144]. In this way, $\mathrm{NiMo} / \mathrm{Al}_{2} \mathrm{O}_{3}$ [136] looks to be the best option, promoting the HDO pathway instead of the HDC/HDCn reactions and showing more resistance against the $\mathrm{CO} / \mathrm{CO}_{2}$ inhibition effect.

The catalyst selectivity strongly depends on the operating conditions (mainly reactor temperature) and catalyst metal composition during deoxygenation. In this sense, a high operating temperature (more than $350{ }^{\circ} \mathrm{C}$ ) or high amount of biomass in the feedstock (more than $10 \mathrm{wt} \%$ ) promote the HDC/HDCn reactions, to the detriment of the HDO pathway. On the other hand, Ni- or Pd-based catalysts promote the HDC/HDCn reactions, while $\mathrm{NiMo} / \mathrm{Al}_{2} \mathrm{O}_{3}$ and $\mathrm{CoMo} / \mathrm{Al}_{2} \mathrm{O}_{3}$ catalysts promote the $\mathrm{HDO}$ pathway [149].

\begin{tabular}{|c|c|c|c|}
\hline Catalysts & Feedstock & $\begin{array}{c}\text { Operating Conditions } \\
\text { (Temperature, }{ }^{\circ} \mathrm{C} / \text { Pressure, } \\
\mathrm{MPa} / \mathrm{L} / \mathrm{W}-\mathrm{HSV}, \mathrm{h}^{-1} \text { ) }\end{array}$ & Reference \\
\hline $\mathrm{NiMo} / \mathrm{Al}_{2} \mathrm{O}_{3}$ (commercial) & $\begin{array}{l}\text { Heavy gas oil/UCO: } \\
90 / 10,70 / 30\end{array}$ & $310,330,350 / 8.4 / \mathrm{LHSV}=1.0$ & [150] \\
\hline $\begin{array}{c}\mathrm{NiMo} / \mathrm{Al}_{2} \mathrm{O}_{3} \\
\mathrm{CoMo} / \mathrm{Al}_{2} \mathrm{O}_{3} \\
\text { (both commercial) }\end{array}$ & $\begin{array}{l}\text { Heavy atmospheric gas oil/UCO: } \\
\qquad 90 / 10,70 / 30\end{array}$ & $330,350,370 / 5.6 / \mathrm{LHSV}=1.0$ & [136] \\
\hline $\mathrm{NiMo} / \mathrm{Al}_{2} \mathrm{O}_{3}$ (commercial) & $\begin{array}{l}\text { AGO/Used frying oil: } \\
\text { 80/20, 50/50 }\end{array}$ & $320,350 / 5.5 / \mathrm{WHSV}=2.0$ & [141] \\
\hline $\mathrm{NiMo} / \mathrm{Al}_{2} \mathrm{O}_{3}$ (commercial) & $\begin{array}{c}\text { SRGO/UCO: } 80 / 20 \\
\text { SRGO/Animal fat: } 80 / 20 \\
\text { SRGO/Palm oil: } 80 / 20\end{array}$ & $350 / 5.5 / \mathrm{LHSV}=2.0$ & [151] \\
\hline $\mathrm{NiMo} / \mathrm{Al}_{2} \mathrm{O}_{3}$ (commercial) & $\begin{array}{l}\text { Light gas oil/RSO: } \\
90 / 10,80 / 20\end{array}$ & $320,350,380 / 3.0,5.0 / \mathrm{LHSV}=2.0$ & [36] \\
\hline $\begin{array}{l}\mathrm{CoMo} / \mathrm{Al}_{2} \mathrm{O}_{3} \\
\text { (commercial) } \\
\mathrm{NiMo} / \mathrm{Al}_{2} \mathrm{O}_{3} \\
\text { (synthesized) }\end{array}$ & $\begin{array}{l}\text { SRGO/Jatropha oil: } \\
90 / 10,80 / 20,70 / 30,60 / 40,50 / 50\end{array}$ & $300 / 5.0$ & [152] \\
\hline $\begin{array}{c}\mathrm{NiW} / \mathrm{SiO}_{2}-\mathrm{Al}_{2} \mathrm{O}_{3} \\
\mathrm{NiMo} / \mathrm{Al}_{2} \mathrm{O}_{3}\end{array}$ & Gas oil/UCO: 75/25 & $340-380 / 5.0 / \mathrm{LHSV}=2.0,4.0$ & [153] \\
\hline $\begin{array}{l}\mathrm{NiMo} / \mathrm{Al}_{2} \mathrm{O}_{3} \\
\text { (commercial) }\end{array}$ & $\begin{array}{l}\text { Heavy vacuum gas oil/canola oil: } \\
\qquad 95 / 5,90 / 10,80 / 20\end{array}$ & 360-395/8.0-10.0/LHSV = 1.0-2.5 & [154] \\
\hline $\begin{array}{l}\mathrm{CoMo} / \gamma-\mathrm{Al}_{2} \mathrm{O}_{3} \\
\text { (commercial) }\end{array}$ & $\begin{array}{l}\text { Gas oil/Palm oil: } \\
95 / 5,90 / 10\end{array}$ & $330,350,365 / 3.3 / \mathrm{WHSV}=0.85,1.0,1.4$ & [155] \\
\hline NiW /(Pseudoboehmite + SBA-15 & $\mathrm{LCO} / \mathrm{WCO} 50 / 50$ & $365 / 9.5 / 75 \mathrm{~min}$ & [156] \\
\hline $\begin{array}{c}\mathrm{Mo} / \mathrm{Al}_{2} \mathrm{O}_{3}+ \\
\left.\mathrm{NiMo} / \mathrm{Al}_{2} \mathrm{O}_{3}-\mathrm{SAPO}-11\right)\end{array}$ & $\begin{array}{l}\text { SRGO/RSO } \\
70 / 30\end{array}$ & $350,380 / 4.0-7.0 /$ LHSV $=1.0-1.5$ & [157] \\
\hline $\begin{array}{l}\mathrm{CoMo} / \mathrm{Al}_{2} \mathrm{O}_{3} \\
\text { (commercial) }\end{array}$ & $\begin{array}{l}\text { Gas oil/cottonseed oil: } \\
\text { 90/10 }\end{array}$ & 305-345/3.0/WHSV = 5-25 & [158] \\
\hline
\end{tabular}

Table 6. The list of heterogeneous catalysts used for green diesel. 


\subsection{Sulphur-Free Catalysts}

The increase of oxygen content compounds in the feedstock (more than $20 \mathrm{wt} \%$ ) significantly promotes sulfur leaching of sulfur from the catalyst surface during hydrotreating [148], which decreases the HDS efficiency during triacylglycerols co-processing. In this way, it is mandatory to find and study new materials that used hydrotreating catalysts and overcome this problem.

The sulphur-free catalysts, such as molybdenum carbide, nitride, and phosphide catalysts, present a promising method of resolving problematic sulphur-leaching due to sulphur not being needed to maintain its activity. Previous studies have shown their suitability for the hydrogenation of middle distillates or vegetable oils $[159,160]$, based on their capacity of adsorbing $\mathrm{H}_{2}$, and transferring them to the reactant molecules. According to these studies, the MoCx and MoNx looked to be the most active. For the MoCx catalysts, an increase in reaction temperature resulted in decreased deoxygenation activity, favouring hydrocracking behaviour. In the case of MoNx catalysts, they showed a higher tendency for hydrocracking and a higher feed rate effect than reaction temperature.

In the middle distillates hydrotreating, those MoCx and MoNx catalysts showed the significant activity of HDS and HDN, observing values of 75\% for HDS and 35-40\% for $\mathrm{HDN}$ rates with $\mathrm{MoCx}$ and $\mathrm{MoNx}$ supported on $\mathrm{Al}_{2} \mathrm{O}_{3}$ and $\mathrm{TiO}_{2}$. In the case of coprocessing, these catalysts also showed significant activity, converting all the triglycerides into paraffin [161]. Table 7 shows a list of sulphur-free carbide/nitride heterogeneous catalysts used for green diesel production.

Table 7. List of Sulphur free carbide/nitride heterogeneous catalysts using for green diesel by vegetable oil hydrotreating or co-processing with petroleum feedstocks.

\begin{tabular}{|c|c|c|c|}
\hline Catalysts & Feedstock & $\begin{array}{l}\text { Operating Conditions } \\
\text { (Temperature, }{ }^{\circ} \mathrm{C} / \text { Pressure, } \mathrm{MPa} / \mathrm{L} / \mathrm{W}-\mathrm{HSV}, \mathrm{h}^{-1} \text { ) }\end{array}$ & Reference \\
\hline $\begin{array}{c}\mathrm{NiMoCx} / \mathrm{Al}_{2} \mathrm{O}_{3} \\
\mathrm{CoMoCx} / \mathrm{Al}_{2} \mathrm{O}_{3} \\
\mathrm{NiMoCx} / \mathrm{TiO}_{2} \\
\mathrm{CoMoCx} / \mathrm{TiO}_{2}\end{array}$ & $\begin{array}{c}\text { AGO/RSO: } \\
95 / 5,90 / 10,75 / 25\end{array}$ & $330,340,350 / 5.5 /$ WHSV $=1.0,2.0$ & [162] \\
\hline $\mathrm{Mo}_{2} \mathrm{C} /$ Activated carbon & Rapeseed oil and Soya oil & $360,380 / 2.0-3.0 / 2 \mathrm{~h}$ (batch reactor) & [163] \\
\hline $\mathrm{NiS}, \mathrm{NiPx}, \mathrm{NiCx}$ & Spent coffee oil & $375,425 / 2.0-4.0 / 3 \mathrm{~h}$ (batch reactor) & [164] \\
\hline MoNx, MoCx, MoPx & Rapeseed oil & $350,370,390 / 5.5 /$ WHSV $=1.0,2.0,4.0$ & [165] \\
\hline $\mathrm{Mo}_{2} \mathrm{C} / \mathrm{C}$ and $\mathrm{Ru} / \mathrm{Al}_{2} \mathrm{O}_{3}$ & Canola oil & $300 / \mathrm{WHSV}=5-25 \mathrm{~h}^{-1}$ & [166] \\
\hline NiMoCx & Soybean oil & $400 / 4.5 / \mathrm{LHSV}=1.0$ & [167] \\
\hline $\begin{array}{c}\mathrm{MoCx} / \mathrm{Al}_{2} \mathrm{O}_{3} \\
\mathrm{MoCx} / \mathrm{TiO}_{2} \\
\mathrm{MoCx} / \mathrm{ZrO}_{2} \\
\mathrm{MoNx} / \mathrm{Al}_{2} \mathrm{O}_{3} \\
\mathrm{MoNx} / \mathrm{TiO}_{2} \\
\mathrm{MoNx} / \mathrm{ZrO}_{2} \\
\end{array}$ & $\begin{array}{c}\text { AGO/RSO: } \\
95 / 5,90 / 10,75 / 25\end{array}$ & $330,340,350 / 5.5 / \mathrm{WHSV}=1.0,2.0$ & [161] \\
\hline $\begin{array}{c}\mathrm{PMoCx} / \mathrm{Al}_{2} \mathrm{O}_{3} \\
(\mathrm{P} \text { content } 0.0-4.5)\end{array}$ & $\begin{array}{c}\text { AGO/RSO: } \\
95 / 5,90 / 10,75 / 25\end{array}$ & $330,340,350 / 5.5 /$ WHSV $=1.0,2.0$ & [168] \\
\hline
\end{tabular}

However, in cases where deep desulfurization of middle distillates is needed, the conventional hydrotreating catalysts $\left(\mathrm{NiMoSx} / \mathrm{Al}_{2} \mathrm{O}_{3}\right.$ and $\mathrm{CoMoSx} / \mathrm{Al}_{2} \mathrm{O}_{3}$ ) seem to be more efficient. A simple means of increasing the activity of sulphur-free catalysts is to add $\mathrm{Co}$ or $\mathrm{Ni}$ as promotors to the structure of the catalysts. This addition increases the catalyst activity significantly due to the ensemble and ligand effects. The effect of promotor addition has already been described for hydrotreating model molecules $[169,170]$ and industrial feedstocks [162], resulting in a significant increase in HDS activity of the MoCx of up to $80 \%$. This activity is comparable with conventional hydrotreating catalysts, but 
the HDN is still low. In this way, other metals, such as phosphorus, promote the HDN efficiency of MoCx catalysts by having a synergistic effect on the catalyst's active sites.

According to current research, the phosphorus addition on MoCx catalysts affects catalyst properties and hydrotreating effectiveness. Figure 5 shows the effect of phosphorus on catalyst activity.

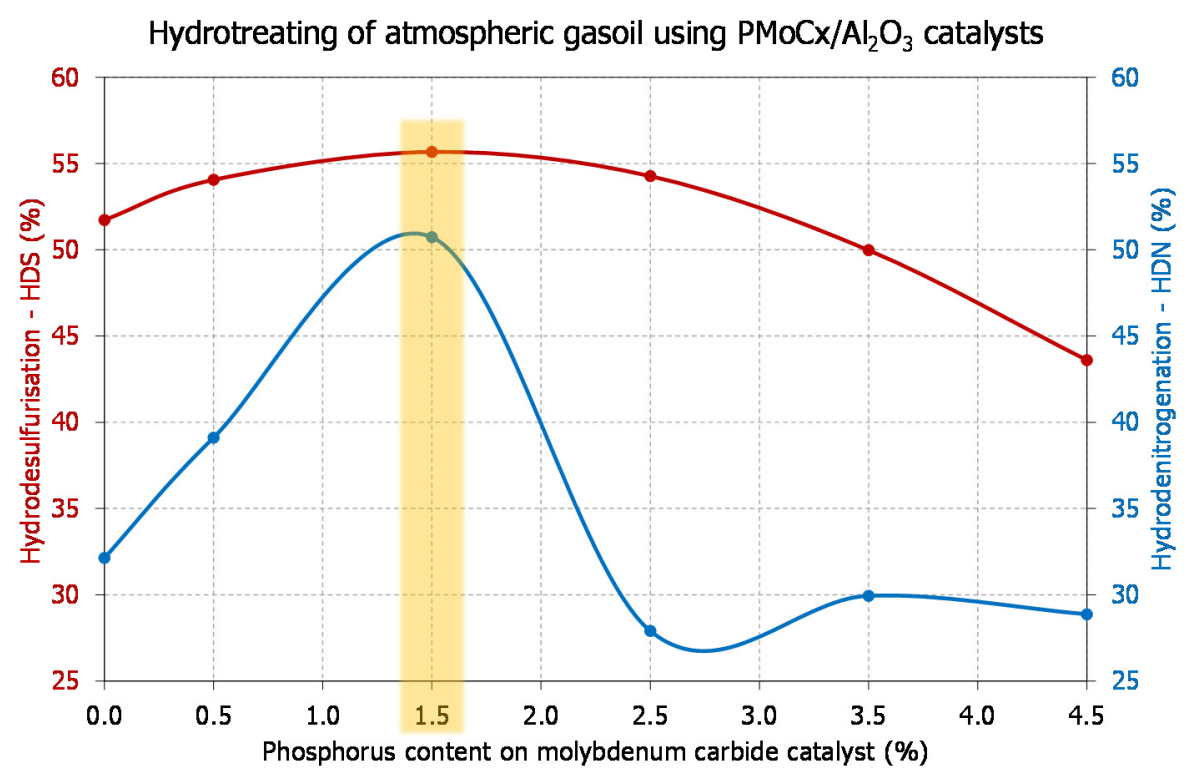

Figure 5. Effect of phosphorus addition on hydrotreating activity of $\mathrm{MoCx} / \mathrm{Al}_{2} \mathrm{O}_{3}$ catalyst. Red line represents HDS efficiency and it is read at left axis. Blue line represents HDN efficiency and it is read at right axis.

Thus, it was possible to claim that adding up to $1.5 \%$ of phosphorus on MoCx catalysts resulted in a moderate increase of catalyst acidity, the formation of strong acid sites, and higher reducibility of catalysts. This fact significantly improves hydrogenation activity, HDS (5-10\%), and HDN (10-25\%) efficiencies during the middle distillates hydrotreating.

The following research is expected to focus on phosphorus development promoting $\mathrm{Co} / \mathrm{Ni}$-Mo carbide and nitride catalysts for co-processing to obtain similar activity as conventional hydrotreating catalysts. In this sense, using these kinds of catalysts represents a suitable alternative for current refineries interested in using their hydrotreating units without significant changes in their schema and a flexible process that allows high-quality biofuel production.

\section{The Used Oil as Bio-Lubricants}

An attractive way to utilise vegetable oils is their use as bio-lubricants that reduce the wear of machines and decrease friction between two surfaces [171]. The vegetable oils have great potential to replace lubricants produced from petroleum oil, known as mineralbased oils, which are obtained when refining crude oil (distillate fraction from the vacuum distillation). Crude oil reserves are relatively depleting and increasing environmental pollution because they introduce harmful materials (heavy metals, sulphur compounds) into the environment and air by their volatility.

The main advantages of using bio-lubricants are: (i) Less emission due to the high boiling point of esters; (ii) not containing aromatic carbohydrates, meaning over $90 \%$ is degradable; (iii) not being harmful to living organisms; (iv) equal or longer tool life due to a higher wetting tendency caused by polar groups of esters reducing friction; (v) the viscosity index not varying much over a wide temperature range; and (vi) being cheaper on account of less maintenance, as well as storage and disposal costs. On the other hand, the disadvantages are (compared to bio-lubricants from crude oils): (i) Less chemical stability, 
(ii) being more expensive, (iii) being offered in a smaller range of viscosities than mineral oils; and (iv) being poorly compatible with paints and sealants [172,173].

Generally, lubricants are used in many industries, such as automobile, agriculture, transmission, and others. Mineral-based lubricants are being replaced by bio-lubricants, especially in agriculture, forestry (chainsaw oil), hydroelectric power plants, and so forth, where high biodegradability is the main advantage in the case of release into the environment. The different properties, such as chemical stability, fluidity, chemical stability, flash point, the temperature stability of viscosity, and solubility in water are required for each application. In producing bio-lubricants, we tried to achieve the approximation of the properties of mineral-based oils that are regulated by European and USA standards [174].

The vegetable oils can be used without modification because they have excellent lubricity and a high viscosity index (it gives information about the temperature viscosity behaviour of lubricating oils-a higher viscosity index means higher lubricity at a higher temperature) [175]. Other properties, determined for bio-lubricants, are very similar to those determined for oils/methyl esters, such as cloud point, pour point, flash point, fire point, acid value, oxidative stability, and iodine value (the explanation is in Section 3) [173]. The main limitations of using non-modified oils are (i) the poor properties at low temperature (formation of macro-crystals) and (ii) low oxidative and thermal stability, which are caused by the presence of an acyl group in the molecule of triacylglycerol (contains $\beta$-hydrogen that is the cause of instability). Moreover, the presence of unsaturated fatty acids also supports the instability of oils. These limitations can be suppressed by various methods, such as (i) the direct addition of antioxidants into the formed bio-lubricants, such as vitamin $\mathrm{E}$, vitamin $\mathrm{C}$, or citric acid derivates; (ii) the genetic modification of the fatty acid profile (i.e., decreasing of the content of unsaturated fatty acids); (iii) the catalytic transformation of functional groups present in oils, such as acyl $(\mathrm{C}=\mathrm{O})$, alkoxy $(\mathrm{O}-\mathrm{R})$, and double bonds by different methods, such as epoxidation and esterification/transesterification of vegetable oils (Figure 6) [176]. This method improves stability and low-temperature properties (viscosity and pour point).

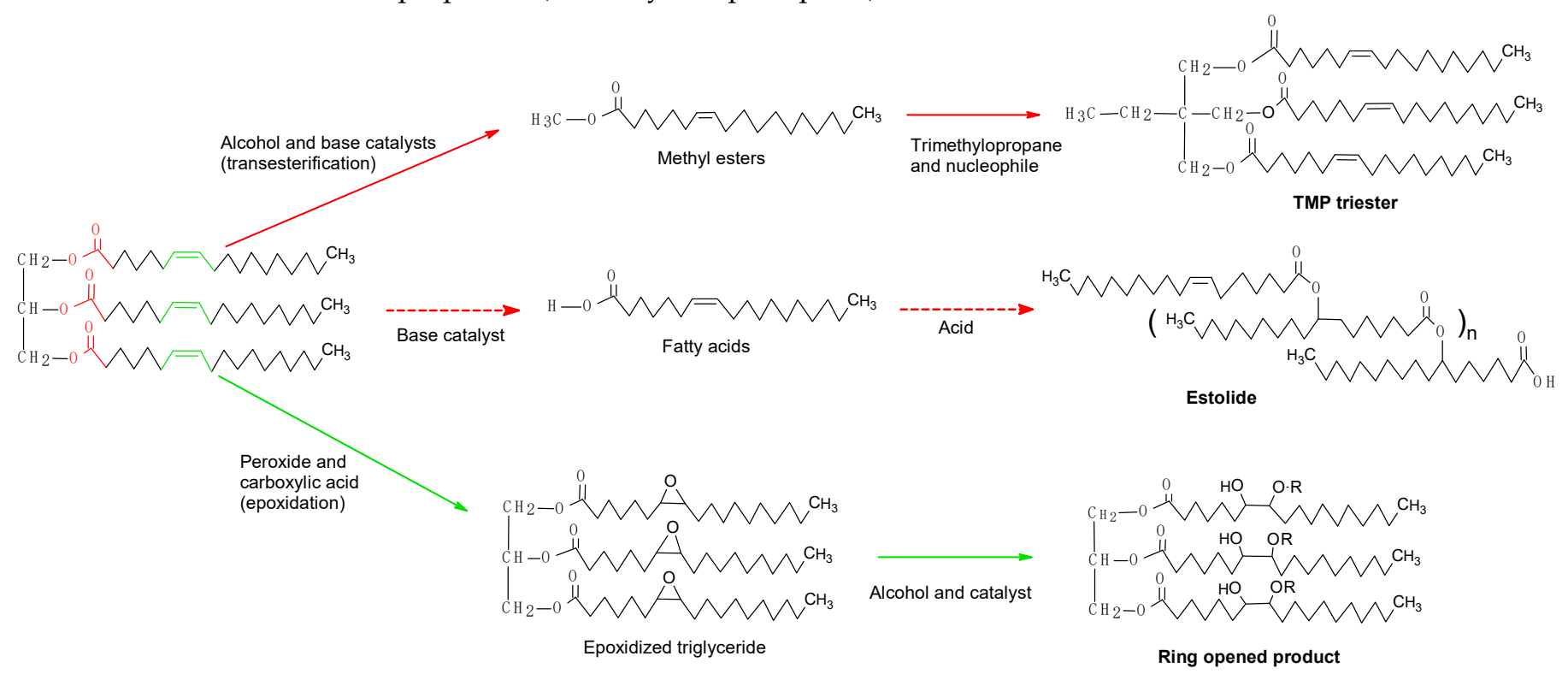

Figure 6. Reaction pathways for preparation of bio-lubricants.

The first modification is the esterification/transesterification of triacylglycerols to form new triesters [177]. This method is similar to the preparation of methyl esters by transesterification reaction (Section 4) because the first step is the preparation of methyl esters by common base-catalysed transesterification. The next step is the reaction of methyl esters with various types of alcohols (trimethylolpropane (TMP), valeric acid, 
pentraerythritol, etc.) to form triesters at the acid or base catalyst. As an alternative, metallic or metal oxides are used as heterogeneous catalysts for esterification (Table 8).

Table 8. The overview of catalysts used for biolubricant triesters.

\begin{tabular}{|c|c|c|c|c|}
\hline Catalysts & Feedstock & $\begin{array}{l}\text { Operating Conditions } \\
\text { (Temp./Pressure/Time/Other) }\end{array}$ & Yield, \% & Ref. \\
\hline Sodium Methoxide & Jatropha oil, TMP & $150{ }^{\circ} \mathrm{C} / 10 \mathrm{mbar} / 3 \mathrm{~h}$ & $>80$ & [178] \\
\hline Sodium Methoxide & Palm ME, TMP & $\begin{array}{c}140{ }^{\circ} \mathrm{C} / 25 \mathrm{mbar} / 25 \mathrm{~min} / \text { oscillatory } \\
\text { flow reactor at } 1.5 \mathrm{~Hz}\end{array}$ & 94.6 & [179] \\
\hline Calcium Methoxide & Palm ME, TMP & $180^{\circ} \mathrm{C} / 50 \mathrm{mbar} / 8 \mathrm{~h}$ & 92.4 & [180] \\
\hline Sodium Methoxide & Canolabiodiesel, ME, TMP & $110^{\circ} \mathrm{C} / 1 \mathrm{mbar} / 5 \mathrm{~h}$ & 90.9 & [181] \\
\hline Dibutyltin dilaurate & Castor biodiesel, TMP & $170^{\circ} \mathrm{C} / 0.01 \mathrm{bar}$ & 89.7 & [182] \\
\hline $\mathrm{KOH}$ & UCO ME, TMP & $128^{\circ} \mathrm{C} / 200 \mathrm{~Pa} / 1.5 \mathrm{~h}$ & 85.7 & [183] \\
\hline Fe-Zn double-metal cyanide & Sunflower oil, octanol & $170^{\circ} \mathrm{C} / 8 \mathrm{~h}$ & 98 & [184] \\
\hline p-Toluensulphonic acid & Rubber ME, NPG/TMP/PE & $\begin{array}{l}135-140{ }^{\circ} \mathrm{C} \text { until theoretical reaction } \\
\text { complete }\end{array}$ & $94.5-96.5$ & [185] \\
\hline C Antarctica lipase & Rapeseed ME, NPG/TMP/PE & $200^{\circ} \mathrm{C} / 50 \mathrm{~h}$ & 98 & [186] \\
\hline p-Toluensulphonic acid & $\begin{array}{l}\text { Thumba ME, xylene, } \\
\text { NPG/TMP/PE }\end{array}$ & $135-140{ }^{\circ} \mathrm{C}$ until complete & $89-95$ & [187] \\
\hline $1 \% \mathrm{NaOCH}_{3}$ & Jatropha seed, TMP & $150{ }^{\circ} \mathrm{C} / 10 \mathrm{mbar} / 3 \mathrm{~h}$ & 47 & [188] \\
\hline $\mathrm{Ca}(\mathrm{OH})_{2}$ & Fluted Pumpkin, TMP & $160^{\circ} \mathrm{C} / 6 \mathrm{~h}$ & 81.4 & [189] \\
\hline $2 \% \mathrm{H}_{2} \mathrm{SO}_{4}$ & Rubber seed, TMP & $150^{\circ} \mathrm{C} / 5 \mathrm{~h}$ & 79 & [190] \\
\hline $0.9 \% \mathrm{NaOCH}_{3}$ & Palm oil, TMP & $130^{\circ} \mathrm{C} / 10 \mathrm{mmHg} / 4 \mathrm{~h}$ & 97.8 & [191] \\
\hline $0.8 \%$ o-phosphoric acid & Castor seed, TMP & $120^{\circ} \mathrm{C} / 1 \mathrm{~h}$ & 96.6 & [192] \\
\hline
\end{tabular}

They can be easily separated compared to homogeneous catalysts. However, they are prone to deactivate from coking and are usually more expensive [193]. The formation of triesters significantly improves properties at low temperatures and thermal-oxidative stability $[176,185]$.

Another modification is to form estolides from the acyl group by hydrolysis of triacylglycerols to obtain various esters. In the reaction, a carbocation is formed at the site of unsaturation, which can undergo nucleophilic attack by other fatty acids to form an ester bond. The functional group carboxylic acid is bonded by double bonds to another fatty acid, and the estolides are formed in the presence of catalysts or without catalysts (Table 9). The fatty acids are usually prepared from triacylglycerols by hydrolysis. The bio-lubricants based on estolide treatment improved the oxidative stability, low-temperature properties, and also lubricity [194].

Table 9. The overview of catalysts used for estolides.

\begin{tabular}{|c|c|c|c|c|}
\hline Catalysts & Feedstock & $\begin{array}{c}\text { Operating Conditions } \\
\text { (Temp./Pressure/Time/Other) }\end{array}$ & Yield, \% & Ref. \\
\hline $\begin{array}{c}\mathrm{H}_{2} \mathrm{SO}_{4}, \mathrm{HClO}_{4} \text {, or } \\
\text { p-Toluensulphonic acid }\end{array}$ & Sunflower oil & 50-100 (depending on catalyst)/3-24 & - & [195] \\
\hline $\mathrm{H}_{2} \mathrm{SO}_{4}$ & Olive oil & $100 / 3-24 \mathrm{~h}$ & - & [195] \\
\hline $\begin{array}{c}\mathrm{H}_{2} \mathrm{SO}_{4}, \mathrm{HClO}_{4} \text {, or } \\
\text { p-Toluensulphonic acid }\end{array}$ & Ricinoleic acid & $50-100{ }^{\circ} \mathrm{C}$ (depending on catalyst) & - & [196] \\
\hline Tin (II) 2-ethylhexanoate & Castor 2-EH ester, lauric acid & $130{ }^{\circ} \mathrm{C} / 12-18 \mathrm{~Pa} / 24 \mathrm{~h}$ & 73 & [197] \\
\hline- & $\begin{array}{l}\text { Castor 2-EH ester, estolide, } \\
\text { butanethiol }\end{array}$ & $\begin{array}{c}-28 \text { to }-18{ }^{\circ} \mathrm{C} / 3 \mathrm{~h} / \text { photochemical } \\
\text { reactor }\end{array}$ & 91 & [197] \\
\hline
\end{tabular}


Table 9. Cont.

\begin{tabular}{|c|c|c|c|c|}
\hline Catalysts & Feedstock & $\begin{array}{c}\text { Operating Conditions } \\
\text { (Temp./Pressure/Time/Other) }\end{array}$ & Yield, \% & Ref. \\
\hline- & $\begin{array}{l}\text { Saturated Castor FA ester, } \\
\text { capping FA }\end{array}$ & $200^{\circ} \mathrm{C} / 20 \mathrm{~Pa} / 24 \mathrm{~h}$ & - & [198] \\
\hline- & $\begin{array}{l}\text { Unsaturated Castor FA } \\
\text { ester, capping FA }\end{array}$ & $200{ }^{\circ} \mathrm{C} / 20 \mathrm{~Pa} / 24 \mathrm{~h}$ & - & [198] \\
\hline $\mathrm{BF}_{3}$ & $\begin{array}{l}\text { Oleic acid estolide, linear } \\
\text { alcohols }\end{array}$ & $60-80{ }^{\circ} \mathrm{C}$ until $99 \%$ complete & - & [199] \\
\hline $\mathrm{HClO}_{4}$ & $\begin{array}{c}\text { Coriander FA, 2-EH, capped } \\
\text { with various FA }\end{array}$ & $\begin{array}{c}\text { Estolide: } 60^{\circ} \mathrm{C} / 7.5-10.9 \mathrm{kPa} / 24 \mathrm{~h} \\
\text { Ester: additional 3-4 h after 2-EH added }\end{array}$ & $65-76$ & [200] \\
\hline- & $\begin{array}{l}\text { Castor 2-EH ester estolide, } \\
\text { butanethiol }\end{array}$ & $\begin{array}{c}-28 \text { to }-18^{\circ} \mathrm{C} / 3 \mathrm{~h} / \text { photochemical } \\
\text { reactor }\end{array}$ & 96 & [197] \\
\hline
\end{tabular}

The last modification is epoxidation, which removes the double bonds between two carbons in fatty acids by bonding an oxygen atom, whereby the epoxide (oxirane) functional group is formed. The oils/fats reacted with oxidants (hydrogen peroxide) in the presence of formic or acetic acid, sometimes involving the use of various enzymatic or heterogeneous catalysts, such as Amberlite IR- $120 \mathrm{H}$, sulfuric acid, and the sulfated- $\mathrm{SnO}_{2}$ catalyst (Table 10) [177].

Table 10. The overview of catalysts used for biolubricant synthesis by epoxidation.

\begin{tabular}{|c|c|c|c|c|}
\hline Catalysts & Feedstock & Operating Conditions (Temper./Time/Other) & Yield, \% & Ref. \\
\hline- & Oleic acid, formic acid, $\mathrm{H}_{2} \mathrm{O}_{2}$ & $4{ }^{\circ} \mathrm{C} / 2 \mathrm{~h}$ & - & [201] \\
\hline- & $\begin{array}{l}\text { Passion fruit oil, formic acid, } \\
\qquad \mathrm{H}_{2} \mathrm{O}_{2}\end{array}$ & $10{ }^{\circ} \mathrm{C}$ then adding $\mathrm{H}_{2} \mathrm{O}_{2}$ and heating to $60^{\circ} \mathrm{C}, 7 \mathrm{~h}$ & - & [202] \\
\hline $\mathrm{H}_{2} \mathrm{SO}_{4}$ & Jatropha oil, formic acid, $\mathrm{H}_{2} \mathrm{O}_{2}$ & $\begin{array}{l}10^{\circ} \mathrm{C} \text { for } 2 \mathrm{~h} \text { while } \mathrm{H}_{2} \mathrm{O}_{2} \text { added then } 60^{\circ} \mathrm{C} \text { until } \\
\text { complete }\end{array}$ & 96 & [203] \\
\hline $\begin{array}{l}\text { Sulfated-SnO } \\
\text { Catalyst }\end{array}$ & Canola oil, acetic acid, $\mathrm{H}_{2} \mathrm{O}_{2}$ & $70^{\circ} \mathrm{C} / 6.5 \mathrm{~h}$ & - & [204] \\
\hline- & Methyl oleate, formic acid, $\mathrm{H}_{2} \mathrm{O}_{2}$ & - & 97 & [205] \\
\hline $\begin{array}{l}\mathrm{H}_{2} \mathrm{SO}_{4}, \mathrm{H}_{3} \mathrm{NSO}_{3} \text {, or } \\
\mathrm{CH}_{4} \mathrm{O}_{3} \mathrm{~S}\end{array}$ & Epoxidized mustard oil, 2-EH & $120^{\circ} \mathrm{C}$ until complete & $92-95$ & [206] \\
\hline Sulfated Ti-SBA-15 & $\begin{array}{l}\text { Epoxidized canola oil, acetic } \\
\text { anhydride }\end{array}$ & $130^{\circ} \mathrm{C} / 5 \mathrm{~h}$ & 100 & [207] \\
\hline $\mathrm{H}_{2} \mathrm{SO}_{4}$ & $\begin{array}{l}\text { Epoxidized soybean oil, Guerbet } \\
\text { alcohols }\end{array}$ & $110^{\circ} \mathrm{C} / 20 \mathrm{~h} / 0.47 \mathrm{~mol}$ alcohol & - & [208] \\
\hline $\mathrm{CaO}$ & $\begin{array}{l}\text { Epoxidized FA UCO ME, } \\
\text { methanol, isooctadecanol }\end{array}$ & $90-140{ }^{\circ} \mathrm{C}$ & - & [209] \\
\hline Pyridine & $\begin{array}{c}\text { 9,10-hydroxyacyloxy-stearic acid } \\
\mathrm{ME}, \mathrm{CCl}_{4} \text {, acylchlorides }\end{array}$ & $50{ }^{\circ} \mathrm{C} / 5 \mathrm{~h}$ & $66-88$ & [210] \\
\hline p-toluensulphonic acid & $\begin{array}{l}\text { Monoepoxide linoleic acid, oleic } \\
\text { acid }\end{array}$ & $\begin{array}{l}70-80{ }^{\circ} \mathrm{C} \text { oleic acid added over } 1.5 \mathrm{~h} \text { then heated to } \\
\qquad 90-110^{\circ} \mathrm{C} \text { over } 3-6 \mathrm{~h}\end{array}$ & - & [211] \\
\hline Amberlyst-15 & Epoxidized canola oil, n-butanol & $100^{\circ} \mathrm{C} / 15 \mathrm{~h}$ & - & [212] \\
\hline p-toluensulphonic acid & $\begin{array}{c}\text { Epoxidized linseed oil, oleic acid, } \\
\text { xylene }\end{array}$ & $150^{\circ} \mathrm{C} / 4-5 \mathrm{~h}$ & - & [213] \\
\hline
\end{tabular}

The reason is that oils are non-polar matter, and the change of double bonds to the epoxide group change the polarity (polar matter is formed), which provide better adsorption on the surface of materials in the engine (better lubricity). Moreover, epoxidation increases oxidation stability. On the other hand, epoxidation decreases the viscosity index and increases the pour point. This fact limits the use of bio-lubricants in many applications, mainly due to the pour point [208]. This problem can be solved by opening the epoxide 
ring and adding another functional group, such as various fatty acids and acetyl, which also increases polarity. These processes are usually catalysed by acid catalysts, such as ptoluenesulfonic acid, which is homogeneous, or various zeolites, which are heterogeneous. The formed bio-lubricants have better properties than epoxides [206].

\section{Conclusions and Prospects}

Vegetable oils or animal fats represent an important source of reusable energy. This paper summarised and compared the transformation of oils/fats to biofuels. For biofuels, two main methods were described: (i) esterification or transesterification to biodiesel, and (ii) co-processing or hydroprocessing to green diesel. Biodiesel is a mixture of esters of higher fatty acids and low molecular alcohol (not paraffinic). In contrast, green diesel is a strongly paraffinic biofuel with lower density, higher cetane index, and flammability. A detailed comparison of biodiesel and green diesel properties was introduced. The production of green diesel is compatible with the current petrochemical infrastructure and allows for an efficient transition to a long-term sustainable energy perspective (the industrial scale is possible). The transformations are usually catalysed by many types of catalysts, such as homogeneous (e.g., $\mathrm{KOH}, \mathrm{H}_{2} \mathrm{SO}_{4}$ ) or heterogeneous (e.g., $\mathrm{CaO}$, mixed oxides, zeolites, heteropolyacids, molybdenum carbide or nitrides). The production of bio-lubricants also decreases the consumption of crude oil. Moreover, biofuels and biolubricants are more environmentally friendly than similar products produced from crude oil.

Future research will focus on developing the stable catalyst with a higher yield at lower production costs and looking for a new cheap source of oils/fats, such as waste or non-food oils. For esters, we will be looking for new applications, such as the transformation to bio-lubricants, epoxidation to monomers, or additives to oil.

Author Contributions: Conceptualization, M.H.; resources, A.V.; writing-original draft preparation, M.H., A.V., H.d.P.C. and J.K.; writing—review and editing, M.H.; visualization, A.V. All authors have read and agreed to the published version of the manuscript.

Funding: This work was supported by the Czech Science Foundation Project No. 19-00669S. The result was achieved using the infrastructure included in the project, Efficient Use of Energy Resources Using Catalytic Processes (LM2018119) which has been financially supported by MEYS within the targeted support of large infrastructures.

Conflicts of Interest: The authors declare no conflict of interest.

$\begin{array}{ll}\text { Abbreviations } \\ \text { AGO } & \text { Atmospheric gasoil } \\ \text { DG } & \text { Diacylglycerols(s) } \\ \text { E } & \text { Ester(s) } \\ \text { EP } & \text { The ester phase } \\ \text { EH } & \text { Ethylhexyl } \\ \text { FAME } & \text { Fatty acid methyl ester } \\ \text { FFA } & \text { Free fatty acid(s) } \\ \text { HDS } & \text { Hydrodesulfurization } \\ \text { HDN } & \text { Hydrodenitrogenation } \\ \text { HDO } & \text { Hydrodeoxygenation } \\ \text { HVO } & \text { Hydrotreated vegetable oil } \\ \text { G } & \text { Glycerol } \\ \text { GP } & \text { The glycerol phase } \\ \text { ME } & \text { Methyl esters } \\ \text { MG } & \text { Monoacylglycerols(s) } \\ \text { RSO } & \text { Rapeseed oil } \\ \text { SRGO } & \text { Straight run gas oil } \\ \text { TG } & \text { Triacylglycerol(s) } \\ \text { TOFA } & \text { Tall oil fatty acids } \\ \text { UCO } & \text { Used cooking oil }\end{array}$




\section{References}

1. Rutter, P.; Keirstead, J. A brief history and the possible future of urban energy systems. Energ Policy 2012, 50, 72-80. [CrossRef]

2. Rodrigue, J.P. The Geography of Transport. Systems; Taylor \& Francis: New York, NY, USA, 2020.

3. Atadashi, I.M.; Aroua, M.K.; Aziz, A.A. Biodiesel separation and purification: A review. Renew. Energy 2011, 36, 437-443. [CrossRef]

4. Gielen, D.; Boshell, F.; Saygin, D.; Bazilian, M.D.; Wagner, N.; Gorini, R. The role of renewable energy in the global energy transformation. Energy Strateg. Rev. 2019, 24, 38-50. [CrossRef]

5. Aron, N.S.M.; Khoo, K.S.; Chew, K.W.; Show, P.L.; Chen, W.H.; Nguyen, T.H.P. Sustainability of the four generations of biofuels-A review. Int. J. Energy Res. 2020, 44, 9266-9282. [CrossRef]

6. Atadashi, I.M.; Aroua, M.K.; Aziz, A.R.A.; Sulaiman, N.M.N. The effects of catalysts in biodiesel production: A review. J. Ind. Eng. Chem. 2013, 19, 14-26. [CrossRef]

7. Naik, S.N.; Goud, V.V.; Rout, P.K.; Dalai, A.K. Production of first and second generation biofuels: A comprehensive review. Renew. Sustain. Energy Rev. 2010, 14, 578-597. [CrossRef]

8. Singh, D.; Sharma, D.; Soni, S.L.; Sharma, S.; Kumari, D. Chemical compositions, properties, and standards for different generation biodiesels: A review. Fuel 2019, 253, 60-71. [CrossRef]

9. Sims, R.E.H.; Mabee, W.; Saddler, J.N.; Taylor, M. An overview of second generation biofuel technologies. Bioresour. Technol. 2010, 101, 1570-1580. [CrossRef]

10. Carriquiry, M.A.; Du, X.D.; Timilsina, G.R. Second generation biofuels: Economics and policies. Energy Policy 2011, $39,4222-4234$. [CrossRef]

11. Peralta, Y.; Sanchez, E.; Kafarov, V. Exergy Analysis for Third Generation Biofuel Production from Microalgae Biomass. Chem. Eng. Trans. 2010, 21, 1363-1368.

12. Plata, V.; Kafarov, V.; Moreno, N. Optimization of Third Generation Biofuels Production: Biodiesel from Microalgae Oil by Homogeneous Transesterification. Chem. Eng. 2010, 21, 1201-1206.

13. European Parliament. Directive (EU) 2018/2001 of the European Parliament and of the Council of 11 December 2018 on the Promotion of the Use of Energy from Renewable Sources; European Parliament: Brussels, Belgium, 2018.

14. Weaver, J. Biodiesel Industry Overview \& Technical Update; National Biodiesel Board: Jefferson City, MO, USA, 2020.

15. Singh, D.; Sharma, D.; Soni, S.L.; Inda, C.S.; Sharma, S.; Sharma, P.K.; Jhalani, A. A comprehensive review of physicochemical properties, production process, performance and emissions characteristics of 2nd generation biodiesel feedstock: Jatropha curcas. Fuel 2021, 285, 119110. [CrossRef]

16. Kouzu, M.; Hidaka, J. Transesterification of vegetable oil into biodiesel catalyzed by CaO: A review. Fuel 2012, 93, 1-12. [CrossRef]

17. Abomohra, A.E.-F.; Elsayed, M.; Esakkimuthu, S.; El-Sheekh, M.; Hanelt, D. Potential of fat, oil and grease (FOG) for biodiesel production: A critical review on the recent progress and future perspectives. Prog. Energy Combust. Sci. 2020, 81, 100868. [CrossRef]

18. Aitlaalim, A.; Ouanji, F.; Benzaouak, A.; El Mahi, M.; Lotfi, E.; Kacimi, M.; Liotta, L.F. Utilization of Waste Grooved Razor Shell (GRS) as a Catalyst in Biodiesel Production from Refined and Waste Cooking Oils. Catalysts 2020, 10, 703. [CrossRef]

19. Singh, D.; Sharma, D.; Soni, S.L.; Sharma, S.; Sharma, P.K.; Jhalani, A. A review on feedstocks, production processes, and yield for different generations of biodiesel. Fuel 2020, 262, 116553. [CrossRef]

20. Lee, D.S.; Noh, B.S.; Bae, S.Y.; Kim, K. Characterization of fatty acids composition in vegetable oils by gas chromatography and chemometrics. Anal. Chim. Acta 1998, 358, 163-175. [CrossRef]

21. Refaat, A.A. Correlation between the chemical structure of biodiesel and its physical properties. Int. J. Environ. Sci. Technol. 2009, 6, 677-694. [CrossRef]

22. Smidrkal, J.; Filip, V.; Belohlav, Z.; Zamostny, P.; Honig, V. Current State and Prospects of Utilization of Vegetable Oils. Chem. Listy 2008, 102, 984-991.

23. Kocik, J.; Samikannu, A.; Bourajoini, H.; Pham, T.N.; Mikkola, J.P.; Hajek, M.; Capek, L. Screening of active solid catalysts for esterification of tall oil fatty acids with methanol. J. Clean. Prod. 2017, 155, 34-38. [CrossRef]

24. Ramos, M.; Dias, A.P.S.; Puna, J.F.; Gomes, J.; Bordado, J.C. Biodiesel Production Processes and Sustainable Raw Materials. Energies 2019, 12, 4408. [CrossRef]

25. Savoire, R.; Lanoiselle, J.L.; Vorobiev, E. Mechanical Continuous Oil Expression from Oilseeds: A Review. Food Bioprocess Technol. 2013, 6, 1-16. [CrossRef]

26. Bowden, S.A.; Monaghan, P.B.; Wilson, R.; Parnell, J.; Cooper, J.M. The liquid-liquid diffusive extraction of hydrocarbons from a North Sea oil using a microfluidic format. Lab Chip 2006, 6, 740-743. [CrossRef] [PubMed]

27. Widmann, B. Production of vegetable oils in decentral plants and aspects of quality management-Investigations on plants in practice to optimise the process. Biomass Energy Ind. 1998, 124-127.

28. Šmidrkal, J.; Filip, V.; Bělohlav, Z.; Zámostný, P.; Hönig, V. Současný stav a perspektivity využití rostlinného oleje. Chem. Pap. 2008, 102, 984-991.

29. Santori, G.; Di Nicola, G.; Moglie, M.; Polonara, F. A review analyzing the industrial biodiesel production practice starting from vegetable oil refining. Appl. Energy 2012, 92, 109-132. [CrossRef]

30. Demirbas, A. Relationships derived from physical properties of vegetable oil and biodiesel fuels. Fuel 2008, 87, 1743-1748. [CrossRef] 
31. Huo, H.; Wang, M.; Bloyd, C.; Putsche, V. Life-Cycle Assessment of Energy Use and Greenhouse Gas Emissions of SoybeanDerived Biodiesel and Renewable Fuels. Environ. Sci. Technol. 2009, 43, 750-756. [CrossRef] [PubMed]

32. Hill, J.; Nelson, E.; Tilman, D.; Polasky, S.; Tiffany, D. Environmental, economic, and energetic costs and benefits of biodiesel and ethanol biofuels. Proc. Natl. Acad. Sci. USA 2006, 103, 11206-11210. [CrossRef]

33. Geller, D.P.; Goodrum, J.W. Effects of specific fatty acid methyl esters on diesel fuel lubricity. Fuel 2004, 83, 2351-2356. [CrossRef]

34. Bezergianni, S.; Dimitriadis, A. Comparison between different types of renewable diesel. Renew. Sustain. Energy Rev. 2013, 21, 110-116. [CrossRef]

35. Sastry, N.V.; Patel, M.C. Densities, excess molar volumes, viscosities, speeds of sound, excess isentropic compressibilities, and relative permittivities for alkyl (methyl, ethyl, butyl, and isoamyl) acetates plus glycols at different temperatures. J. Chem. Eng. Data 2003, 48, 1019-1027. [CrossRef]

36. Walendziewski, J. Hydroprocessing of Light Cracking Catalytic Oil, Vacuum Gas Oil and Their Blends. Erdol. Kohle Erdgas Petrochem. 1991, 44, 475-479.

37. Simacek, P.; Kubicka, D.; Kubickova, I.; Homola, F.; Pospisil, M.; Chudoba, J. Premium quality renewable diesel fuel by hydroprocessing of sunflower oil. Fuel 2011, 90, 2473-2479. [CrossRef]

38. Geller, D.P.; Goodrum, J.W. Rheology of vegetable oil analogs and triglycerides. J. Am. Oil Chem. Soc. 2000, 77, 111-114. [CrossRef]

39. Liang, X.Z.; Gao, S.; Wu, H.H.; Yang, J.G. Highly efficient procedure for the synthesis of biodiesel from soybean oil. Fuel Process. Technol. 2009, 90, 701-704. [CrossRef]

40. Atadashi, I.M.; Aroua, M.K.; Aziz, A.R.A.; Sulaiman, N.M.N. Production of biodiesel using high free fatty acid feedstocks. Renew. Sustain. Energy Rev. 2012, 16, 3275-3285. [CrossRef]

41. Knothe, G. Dependence of biodiesel fuel properties on the structure of fatty acid alkyl esters. Fuel Process. Technol. 2005, 86, 1059-1070. [CrossRef]

42. Ashraful, A.M.; Masjuki, H.H.; Kalam, M.A.; Fattah, I.M.R.; Imtenan, S.; Shahir, S.A.; Mobarak, H.M. Production and comparison of fuel properties, engine performance, and emission characteristics of biodiesel from various non-edible vegetable oils: A review. Energy Convers. Manag. 2014, 80, 202-228. [CrossRef]

43. Kumar, N.; Varun; Chauhan, S.R. Performance and emission characteristics of biodiesel from different origins: A review. Renew. Sustain. Energy Rev. 2013, 21, 633-658. [CrossRef]

44. Shahabuddin, M.; Liaquat, A.M.; Masjuki, H.H.; Kalam, M.A.; Mofijur, M. Ignition delay, combustion and emission characteristics of diesel engine fueled with biodiesel. Renew. Sustain. Energy Rev. 2013, 21, 623-632. [CrossRef]

45. Hoekman, S.K.; Robbins, C. Review of the effects of biodiesel on NOx emissions. Fuel Process. Technol. 2012, 96, 237-249. [CrossRef]

46. Varatharajan, K.; Cheralathan, M. Influence of fuel properties and composition on NOx emissions from biodiesel powered diesel engines: A review. Renew. Sustain. Energy Rev. 2012, 16, 3702-3710. [CrossRef]

47. Altin, R.; Cetinkaya, S.; Yucesu, H.S. The potential of using vegetable oil fuels as fuel for diesel engines. Energy Convers. Manag. 2001, 42, 529-538. [CrossRef]

48. Miao, X.L.; Wu, Q.Y. Biodiesel production from heterotrophic microalgal oil. Bioresour. Technol. 2006, 97, 841-846. [CrossRef]

49. Firoz, S. A review: Advantages and Disadvantages of Biodiesel. Int. Res. J. Eng. Technol. 2017, 4, 530-535.

50. Hollebone, B.; Yang, Z. Biofuels in the environment: A review of behaviours, fates, effects and possible remediation techniques. In Proceedings of the 32. AMOP Technical Seminar on Environmental Contamination and Response, Ottawa, ON, Canada, 9-11 June 2009.

51. Ardi, M.S.; Aroua, M.K.; Hashim, N.A. Progress, prospect and challenges in glycerol purification process: A review. Renew. Sustain. Energy Rev. 2015, 42, 1164-1173. [CrossRef]

52. Meher, L.C.; Sagar, D.V.; Naik, S.N. Technical aspects of biodiesel production by transesterification-A review. Renew. Sustain. Energy Rev. 2006, 10, 248-268. [CrossRef]

53. Hajek, M.; Skopal, F.; Kwiecien, J. Biodiesel preparation in a batch emulsification reactor. Eur. J. Lipid Sci. Technol. 2009, 111, 979-984. [CrossRef]

54. Hajek, M.; Vavra, A.; Mach, P.; Strakova, A. The use of cosolvents in heterogeneously and homogeneously catalysed methanolysis of oil. J. Environ. Manag. 2020, 262, 110295. [CrossRef]

55. Cernoch, M.; Hajek, M.; Skopal, F. Study of effects of some reaction conditions on ethanolysis of rapeseed oil with dispergation. Bioresour. Technol. 2010, 101, 1213-1219. [CrossRef]

56. Cernoch, M.; Hajek, M.; Skopal, F. Relationships among flash point, carbon residue, viscosity and some impurities in biodiesel after ethanolysis of rapeseed oil. Bioresour. Technol. 2010, 101, 7397-7401. [CrossRef] [PubMed]

57. Hajek, M.; Skopal, F.; Capek, L.; Cernoch, M.; Kutalek, P. Ethanolysis of rapeseed oil by KOH as homogeneous and as heterogeneous catalyst supported on alumina and CaO. Energy 2012, 48, 392-397. [CrossRef]

58. Hajek, M.; Skopal, F.; Vavra, A.; Kocik, J. Transesterification of rapeseed oil by butanol and separation of butyl ester. J. Clean. Prod. 2017, 155, 28-33.

59. Nimcevic, D.; Puntigam, R.; Worgetter, M.; Gapes, J.R. Preparation of rapeseed oil esters of lower aliphatic alcohols. J. Am. Oil Chem. Soc. 2000, 77, 275-280. [CrossRef]

60. Leung, D.Y.C.; Wu, X.; Leung, M.K.H. A review on biodiesel production using catalyzed transesterification. Appl. Energy 2010, 87, 1083-1095. [CrossRef] 
61. Hajek, M.; Vavra, A.; Muck, J. Butanol as a co-solvent for transesterification of rapeseed oil by methanol under homogeneous and heterogeneous catalyst. Fuel 2020, 277, 118239. [CrossRef]

62. Kusdiana, D.; Saka, S. Kinetics of transesterification in rapeseed oil to biodiesel fuel as treated in supercritical methanol. Fuel 2001, 80, 693-698. [CrossRef]

63. Zeng, D.; Yang, L.; Fang, T. Process optimization, kinetic and thermodynamic studies on biodiesel production by supercritical methanol transesterification with CH3ONa catalyst. Fuel 2017, 203, 739-748. [CrossRef]

64. Andreo-Martinez, P.; Garcia-Martinez, N.; Duran-del-Amor, M.D.; Quesada-Medina, J. Advances on kinetics and thermodynamics of non-catalytic supercritical methanol transesterification of some vegetable oils to biodiesel. Energy Convers. Manag. 2018, 173, 187-196. [CrossRef]

65. Santos, S.; Puna, J.; Gomes, J. A Review on Bio-Based Catalysts (Immobilized Enzymes) Used for Biodiesel Production. Energies 2020, 13, 3013. [CrossRef]

66. Lopez-Fernandez, J.; Benaiges, M.D.; Valero, F. Rhizopus oryzae Lipase, a Promising Industrial Enzyme: Biochemical Characteristics, Production and Biocatalytic Applications. Catalysts 2020, 10, 1277. [CrossRef]

67. Aarthy, M.; Saravanan, P.; Gowthaman, M.K.; Rose, C.; Kamini, N.R. Enzymatic transesterification for production of biodiesel using yeast lipases: An overview. Chem. Eng. Res. Des. 2014, 92, 1591-1601. [CrossRef]

68. Vyas, A.P.; Verma, J.L.; Subrahmanyam, N. A review on FAME production processes. Fuel 2010, 89, 1-9. [CrossRef]

69. Veljković, V.B.; Avramović, J.M.; Stamenković, O.S. Biodiesel production by ultrasound-assisted transesterification: State of the art and the perspectives. Renew. Sustain. Energy Rev. 2012, 16, 1193-1209. [CrossRef]

70. Aransiola, E.F.; Ojumu, T.V.; Oyekola, O.O.; Madzimbamuto, T.F.; Ikhu-Omoregbe, D.I.O. A review of current technology for biodiesel production: State of the art. Biomass Bioenergy 2014, 61, 276-297. [CrossRef]

71. Kwiecien, J.; Hajek, M.; Skopal, F. The effect of the acidity of rapeseed oil on its transesterification. Bioresour. Technol. 2009, 100, 5555-5559. [CrossRef]

72. Kwiecien, J.; Hajek, M.; Skopal, F. Combined effect of water and KOH on rapeseed oil methanolysis. Bioresour. Technol. 2010, 101, 3121-3125. [CrossRef]

73. Pullen, J.; Saeed, K. Investigation of the factors affecting the progress of base-catalyzed transesterification of rapeseed oil to biodiesel FAME. Fuel Process. Technol. 2015, 130, 127-135. [CrossRef]

74. Hajek, M.; Kwiecien, J.; Skopal, F. Biodiesel: The influence of dealcoholization on reaction mixture composition after neutralization of catalyst by carbon dioxide. Fuel 2012, 96, 85-89. [CrossRef]

75. Hájek, M.; Vávra, A.; Skopal, F.; Straková, A.; Douda, M. The description of catalyst behaviour during transesterification of rapeseed oil-Formation of micellar emulsion. Renew. Energy 2020, 159, 938-943. [CrossRef]

76. Hajek, M.; Skopal, F.; Machek, J. Simplification of separation of the reaction mixture after transesterification of vegetable oil. Eur. J. Lipid Sci. Technol. 2008, 110, 347-350. [CrossRef]

77. Hajek, M.; Skopal, F. Factors affecting the separation of the reaction mixture after transesterification of rapeseed oil. Eur. J. Lipid Sci. Technol. 2008, 110, 920-925. [CrossRef]

78. Darnoko, D.; Cheryan, M. Kinetics of palm oil transesterification in a batch reactor. J. Am. Oil Chem. Soc. 2000, 77, 1263-1267. [CrossRef]

79. Vavra, A.; Hajek, M.; Skopal, F. The removal of free fatty acids from methyl ester. Renew. Energy 2017, 103, 695-700. [CrossRef]

80. Vavra, A.; Hajek, M.; Skopal, F. Acceleration and simplification of separation by addition of inorganic acid in biodiesel production. J. Clean. Prod. 2018, 192, 390-395. [CrossRef]

81. Phan, A.N.; Phan, T.M. Biodiesel production from waste cooking oils. Fuel 2008, 87, 3490-3496. [CrossRef]

82. Talebian-Kiakalaieh, A.; Amin, N.A.S.; Mazaheri, H. A review on novel processes of biodiesel production from waste cooking oil. Appl. Energy 2013, 104, 683-710. [CrossRef]

83. Guerreiro, L.; Castanheiro, J.E.; Fonseca, I.M.; Martin-Aranda, R.M.; Ramos, A.M.; Vital, J. Transesterification of soybean oil over sulfonic acid functionalised polymeric membranes. Catal. Today 2006, 118, 166-171. [CrossRef]

84. Goff, M.J.; Bauer, N.S.; Lopes, S.; Sutterlin, W.R.; Suppes, G.J. Acid-catalyzed alcoholysis of soybean oil. J. Am. Oil Chem. Soc. 2004, 81, 415-420. [CrossRef]

85. Marchetti, J.M.; Errazu, A.F. Esterification of free fatty acids using sulfuric acid as catalyst in the presence of triglycerides. Biomass Bioenergy 2008, 32, 892-895. [CrossRef]

86. Freedman, B.; Butterfield, R.O.; Pryde, E.H. Transesterification Kinetics of Soybean Oil. J. Am. Oil Chem. Soc. 1986, 63, 1375-1380. [CrossRef]

87. Das, S.; Thakur, A.J.; Deka, D. Two-Stage Conversion of High Free Fatty Acid Jatropha curcas Oil to Biodiesel Using Bronsted Acidic Ionic Liquid and KOH as Catalysts. Sci. World J. 2014, 2014, 180983. [CrossRef] [PubMed]

88. Canakci, M.; Van Gerpen, J. Biodiesel production via acid catalysis. ASABE Trans. 1999, 42, 1203-1210. [CrossRef]

89. Sharma, Y.C.; Singh, B.; Korstad, J. Latest developments on application of heterogenous basic catalysts for an efficient and eco friendly synthesis of biodiesel: A review. Fuel 2011, 90, 1309-1324. [CrossRef]

90. Jayakumar, M.; Karmegam, N.; Gundupalli, M.P.; Gebeyehu, K.B.; Asfaw, B.T.; Chang, S.W.; Ravindran, B.; Awasthi, M.K. Heterogeneous base catalysts: Synthesis and application for biodiesel production? A review. Bioresour. Technol. 2021, $331,125054$. [CrossRef] [PubMed] 
91. Zhou, W.Q.; Zhao, X.Q.; Wang, Y.J.; Zhang, J.Y. Synthesis of diphenyl carbonate by transesterification over lead and zinc double oxide catalyst. Appl. Catal. Gen. 2004, 260, 19-24.

92. Kocik, J.; Hajek, M.; Troppova, I. The factors influencing stability of Ca-Al mixed oxides as a possible catalyst for biodiesel production. Fuel Process. Technol. 2015, 134, 297-302. [CrossRef]

93. Hajek, M.; Kocik, J.; Frolich, K.; Vavra, A. Mg-Fe mixed oxides and their rehydrated mixed oxides as catalysts for transesterification. J. Clean. Prod. 2017, 161, 1423-1431. [CrossRef]

94. Perveen, S.; Hanif, M.A.; Nadeem, R.; Rashid, U.; Azeem, M.W.; Zubair, M.; Nisar, N.; Alharthi, F.A.; Moser, B.R. A Novel Route of Mixed Catalysis for Production of Fatty Acid Methyl Esters from Potential Seed Oil Sources. Catalysts 2021, 11, 811. [CrossRef]

95. Gutierrez-Ortega, N.; Ramos-Ramirez, E.; Serafin-Munoz, A.; Zamorategui-Molina, A.; Monjaraz-Vallejo, J. Use of Co/Fe-Mixed Oxides as Heterogeneous Catalysts in Obtaining Biodiesel. Catalysts 2019, 9, 403. [CrossRef]

96. Albuquerque, M.C.G.; Jimenez-Urbistondo, I.; Santamaria-Gonzalez, J.; Merida-Robles, J.M.; Moreno-Tost, R.; Rodriguez-Castellon, E.; Jimenez-Lopez, A.; Azevedo, D.C.S.; Cavalcante, C.L.; Maireles-Torres, P. CaO supported on mesoporous silicas as basic catalysts for transesterification reactions. Appl. Catal. Gen. 2008, 334, 35-43. [CrossRef]

97. Hussain, F.; Alshahrani, S.; Abbas, M.M.; Khan, H.M.; Jamil, A.; Yaqoob, H.; Soudagar, M.E.M.; Imran, M.; Ahmad, M.; Munir, M. Waste Animal Bones as Catalysts for Biodiesel Production; A Mini Review. Catalysts 2021, 11, 630. [CrossRef]

98. Catarino, M.; Ramos, M.; Dias, A.P.S.; Santos, M.T.; Puna, J.F.; Gomes, J.F. Calcium Rich Food Wastes Based Catalysts for Biodiesel Production. Waste Biomass Valoriz. 2017, 8, 1699-1707. [CrossRef]

99. Kant Bhatia, S.; Kant Bhatia, R.; Jeon, J.-M.; Pugazhendhi, A.; Kumar Awasthi, M.; Kumar, D.; Kumar, G.; Yoon, J.-J.; Yang, Y.-H. An overview on advancements in biobased transesterification methods for biodiesel production: Oil resources, extraction, biocatalysts, and process intensification technologies. Fuel 2021, 285, 119117. [CrossRef]

100. Frolich, K.; Vavra, A.; Kocik, J.; Hajek, M.; Jilkova, A. The long-term catalytic performance of mixed oxides in fixed-bed reactors in transesterification. Renew. Energy 2019, 143, 1259-1267. [CrossRef]

101. Di Serio, M.; Tesser, R.; Pengmei, L.; Santacesaria, E. Heterogeneous catalysts for biodiesel production. Energy Fuel 2008, 22, 207-217. [CrossRef]

102. Semwal, S.; Arora, A.K.; Badoni, R.P.; Tuli, D.K. Biodiesel production using heterogeneous catalysts. Bioresour. Technol. 2011, 102, 2151-2161. [CrossRef]

103. Lin, T.; Zhao, S.; Niu, S.; Lyu, Z.; Han, K.; Hu, X. Halloysite nanotube functionalized with La-Ca bimetallic oxides as novel transesterification catalyst for biodiesel production with molecular simulation. Energy Convers. Manag. 2020, $220,113138$. [CrossRef]

104. Kostić, M.D.; Djalović, I.G.; Stamenković, O.S.; Mitrović, P.M.; Adamović, D.S.; Kulina, M.K.; Veljković, V.B. Kinetic modeling and optimization of biodiesel production from white mustard (Sinapis alba L.) seed oil by quicklime-catalyzed transesterification. Fuel 2018, 223, 125-139. [CrossRef]

105. Mohadesi, M.; Aghel, B.; Maleki, M.; Ansari, A. Study of the transesterification of waste cooking oil for the production of biodiesel in a microreactor pilot: The effect of acetone as the co-solvent. Fuel 2020, 273, 117736. [CrossRef]

106. AbdelDayem, H.M.; Salib, B.G.; El-Hosiny, F.I. Facile synthesis of hydrothermal stable hierarchically macro-mesoporous hollow microspheres $\gamma$-Al2O3-graphene oxide composite: As a new efficient acid-base catalyst for transesterification reaction for biodiesel production. Fuel 2020, 277, 118106. [CrossRef]

107. Sulaiman, N.F.; Hashim, A.N.N.; Toemen, S.; Rosid, S.J.M.; Mokhtar, W.N.A.W.; Nadarajan, R.; Abu Bakar, W.A.W. Biodiesel production from refined used cooking oil using co-metal oxide catalyzed transesterification. Renew. Energy 2020, 153, 1-11.

108. Niu, S.L.; Zhang, X.Y.; Ning, Y.L.; Zhang, Y.J.; Qu, T.X.; Hu, X.; Gong, Z.Q.; Lu, C.M. Dolomite incorporated with cerium to enhance the stability in catalyzing transesterification for biodiesel production. Renew. Energy 2020, 154, 107-116. [CrossRef]

109. Qu, T.; Niu, S.; Gong, Z.; Han, K.; Wang, Y.; Lu, C. Wollastonite decorated with calcium oxide as heterogeneous transesterification catalyst for biodiesel production: Optimized by response surface methodology. Renew. Energy 2020, 159, 873-884. [CrossRef]

110. Abukhadra, M.R.; Basyouny, M.G.; El Sherbeeny, A.M.; El Meligy, M.A.; Abb Elgawad, A.E.E. Transesterification of commercial waste cooking oil into biodiesel over innovative alkali trapped zeolite nanocomposite as green and environmental catalysts. Sustain. Chem. Pharm. 2020, 17, 100289. [CrossRef]

111. Abukhadra, M.R.; Sayed, M.A. K+ trapped kaolinite $(\mathrm{Kaol} / \mathrm{K}+)$ as low cost and eco-friendly basic heterogeneous catalyst in the transesterification of commercial waste cooking oil into biodiesel. Energy Convers. Manag. 2018, 177, 468-476. [CrossRef]

112. Borah, M.J.; Das, A.; Das, V.; Bhuyan, N.; Deka, D. Transesterification of waste cooking oil for biodiesel production catalyzed by Zn substituted waste egg shell derived CaO nanocatalyst. Fuel 2019, 242, 345-354. [CrossRef]

113. Bayat, A.; Baghdadi, M.; Bidhendi, G.N. Tailored magnetic nano-alumina as an efficient catalyst for transesterification of waste cooking oil: Optimization of biodiesel production using response surface methodology. Energy Convers. Manag. 2018, 177, 395-405. [CrossRef]

114. Du, L.X.; Ding, S.X.; Li, Z.; Lv, E.M.; Lu, J.; Ding, J.C. Transesterification of castor oil to biodiesel using NaY zeolite-supported La2O3 catalysts. Energy Convers. Manag. 2018, 173, 728-734.

115. Mohamad, M.; Ngadi, N.; Wong, S.L.; Jusoh, M.; Yahya, N.Y. Prediction of biodiesel yield during transesterification process using response surface methodology. Fuel 2017, 190, 104-112. [CrossRef]

116. Navas, M.B.; Lick, I.D.; Bolla, P.A.; Casella, M.L.; Ruggera, J.F. Transesterification of soybean and castor oil with methanol and butanol using heterogeneous basic catalysts to obtain biodiesel. Chem. Eng. Sci. 2018, 187, 444-454. [CrossRef] 
117. Sulaiman, N.F.; Lee, S.L.; Toemen, S.; Bakar, W.Z.W. Physicochemical characteristics of $\mathrm{Cu} / \mathrm{Zn} / \gamma-\mathrm{Al}_{2} \mathrm{O}_{3}$ catalyst and its mechanistic study in transesterification for biodiesel production. Renew. Energy 2020, 156, 142-157. [CrossRef]

118. Rocha, P.D.; Oliveira, L.S.; Franca, A.S. Sulfonated activated carbon from corn cobs as heterogeneous catalysts for biodiesel production using microwave-assisted transesterification. Renew. Energy 2019, 143, 1710-1716. [CrossRef]

119. Gaidukevic, J.; Barkauskas, J.; Malaika, A.; Rechnia-Goracy, P.; Mozdzynska, A.; Jasulaitiene, V.; Kozlowski, M. Modified graphene-based materials as effective catalysts for transesterification of rapeseed oil to biodiesel fuel. Chin. J. Catal. 2018, 39, 1633-1645. [CrossRef]

120. Hajek, M.; Tomasova, A.; Kocik, J.; Podzemna, V. Statistical evaluation of the mutual relations of properties of Mg/Fe hydrotalcites and mixed oxides as transesterification catalysts. Appl. Clay. Sci. 2018, 154, 28-35. [CrossRef]

121. Hajek, M.; Kutalek, P.; Smolakova, L.; Troppova, I.; Capek, L.; Kubicka, D.; Kocik, J.; Thanh, D.N. Transesterification of rapeseed oil by Mg-Al mixed oxides with various Mg/Al molar ratio. Chem. Eng. J. 2015, 263, 160-167. [CrossRef]

122. Vavra, A.; Hajek, M.; Kocian, D. The influence of vegetable oils composition on separation of transesterification products, especially quality of glycerol. Renew. Energy 2021, 176, 262-268. [CrossRef]

123. Hajek, M.; Skopal, F.; Kwiecien, J.; Cernoch, M. Determination of esters in glycerol phase after transesterification of vegetable oil. Talanta 2010, 82, 283-285. [CrossRef]

124. Hajek, M.; Skopal, F.; Cernoch, M. Effect of phase separation temperature on ester yields from ethanolysis of rapeseed oil in the presence of $\mathrm{NaOH}$ and $\mathrm{KOH}$ as catalysts. Bioresour. Technol. 2012, 110, 288-291. [CrossRef]

125. Hajek, M.; Vavra, A.; Skopal, F.; Mekotova, M.; Musil, M. Biodiesel: The study of methyl esters loss in the glycerol phase at various conditions. J. Clean. Prod. 2018, 197, 1573-1578. [CrossRef]

126. Cernoch, M.; Hajek, M.; Skopal, F. Ethanolysis of rapeseed oil—Distribution of ethyl esters, glycerides and glycerol between ester and glycerol phases. Bioresour. Technol. 2010, 101, 2071-2075. [CrossRef]

127. Hajek, M.; Skopal, F. Treatment of glycerol phase formed by biodiesel production. Bioresour. Technol. 2010, 101, 3242-3245. [CrossRef] [PubMed]

128. Kosamia, N.M.; Samavi, M.; Uprety, B.K.; Rakshit, S.K. Valorization of Biodiesel Byproduct Crude Glycerol for the Production of Bioenergy and Biochemicals. Catalysts 2020, 10, 609. [CrossRef]

129. Monteiro, M.R.; Kugelmeier, C.L.; Pinheiro, R.S.; Batalha, M.O.; Cesar, A.D. Glycerol from biodiesel production: Technological paths for sustainability. Renew. Sustain. Energy Rev. 2018, 88, 109-122. [CrossRef]

130. Fontaras, G.; Karavalakis, G.; Kousoulidou, M.; Tzamkiozis, T.; Ntziachristos, L.; Bakeas, E.; Stournas, S.; Samaras, Z. Effects of biodiesel on passenger car fuel consumption, regulated and non-regulated pollutant emissions over legislated and real-world driving cycles. Fuel 2009, 88, 1608-1617. [CrossRef]

131. Katajisto, M. Neste Annual Report 2020; Neste: Helsinki, Finland, 2021.

132. Bezergianni, S. Catalytic Hydroprocessing of Liquid Biomass for Biofuels Production; INTECH Open: London, UK, 2013. [CrossRef]

133. Bezergianni, S.; Dimitriadis, A.; Kikhtyanin, O.; Kubicka, D. Refinery co-processing of renewable feeds. Prog. Energy Combust. Sci. 2018, 68, 29-64. [CrossRef]

134. Cardenas, J.; Orjuela, A.; Sanchez, D.L.; Narvaez, P.C.; Katryniok, B.; Clark, J. Pre-treatment of used cooking oils for the production of green chemicals: A review. J. Clean. Prod. 2021, 289, 125129. [CrossRef]

135. Douvartzides, S.L.; Charisiou, N.D.; Papageridis, K.N.; Goula, M.A. Green Diesel: Biomass Feedstocks, Production Technologies, Catalytic Research, Fuel Properties and Performance in Compression Ignition Internal Combustion Engines. Energies 2019, 12, 809. [CrossRef]

136. Bezergianni, S.; Dimitriadis, A.; Meletidis, G. Effectiveness of CoMo and NiMo catalysts on co-hydroprocessing of heavy atmospheric gas oil-waste cooking oil mixtures. Fuel 2014, 125, 129-136. [CrossRef]

137. Vonortas, A.; Kubicka, D.; Papayannakos, N. Catalytic co-hydroprocessing of gasoil-palm oil/AVO mixtures over a NiMo/gamma$\mathrm{Al}_{2} \mathrm{O}_{3}$ catalyst. Fuel 2014, 116, 49-55. [CrossRef]

138. El-Sawy, M.S.; Hanafi, S.A.; Ashour, F.; Aboul-Fotouh, T.M. Co-hydroprocessing and hydrocracking of alternative feed mixture (vacuum gas oil/waste lubricating oil/waste cooking oil) with the aim of producing high quality fuels. Fuel 2020, $269,117437$. [CrossRef]

139. Gosselink, R.W.; Hollak, S.A.W.; Chang, S.W.; van Haveren, J.; de Jong, K.P.; Bitter, J.H.; van Es, D.S. Reaction Pathways for the Deoxygenation of Vegetable Oils and Related Model Compounds. ChemSusChem 2013, 6, 1576-1594. [CrossRef]

140. Kubickova, I.; Kubicka, D. Utilization of Triglycerides and Related Feedstocks for Production of Clean Hydrocarbon Fuels and Petrochemicals: A Review. Waste Biomass Valoriz. 2010, 1, 293-308. [CrossRef]

141. Carmona, H.D.; Horacek, J.; Alayon, A.B.; Hernandez, J.J.M. Suitability of used frying oil for co-processing with atmospheric gas oil. Fuel 2018, 214, 165-173. [CrossRef]

142. Walendziewski, J.; Stolarski, M.; Luzny, R.; Klimek, B. Hydroprocesssing of light gas oil—Rape oil mixtures. Fuel Process. Technol. 2009, 90, 686-691. [CrossRef]

143. Al-Sabawi, M.; Chen, J.W.; Ng, S. Fluid Catalytic Cracking of Biomass-Derived Oils and Their Blends with Petroleum Feedstocks: A Review. Energy Fuel 2012, 26, 5355-5372. [CrossRef]

144. Bezergianni, S.; Dagonikou, V. Effect of $\mathrm{CO}_{2}$ on catalytic hydrotreatment of gas-oil. Can. J. Chem. Eng. 2015, 93, 1017-1023. [CrossRef] 
145. Bezergianni, S.; Dagonikou, V.; Sklari, S. The suspending role of $\mathrm{H}_{2} \mathrm{O}$ and $\mathrm{CO}$ on catalytic hydrotreatment of gas-oil; myth or reality? Fuel Process. Technol. 2016, 144, 20-26. [CrossRef]

146. Egeberg, R.; Skyum, L.; Zeuthen, P. Hydrotreating in the production of green diesel. Pet. Technol. Q. 2010, 15, 101-113.

147. Imai, H.; Kimura, T.; Terasaka, K.; Li, X.H.; Sakashita, K.; Asaoka, S.; Al-Khattaf, S.S. Hydroconversion of fatty acid derivative over supported Ni-Mo catalysts under low hydrogen pressure. Catal. Today 2018, 303, 185-190. [CrossRef]

148. Kubicka, D.; Horacek, J. Deactivation of HDS catalysts in deoxygenation of vegetable oils. Appl. Catal. Gen. 2011, 394, 9-17. [CrossRef]

149. Veriansyah, B.; Han, J.Y.; Kim, S.K.; Hong, S.A.; Kim, Y.J.; Lim, J.S.; Shu, Y.W.; Oh, S.G.; Kim, J. Production of renewable diesel by hydroprocessing of soybean oil: Effect of catalysts. Fuel 2012, 94, 578-585. [CrossRef]

150. Bezergianni, S.; Dimitriadis, A. Temperature effect on co-hydroprocessing of heavy gas oil-waste cooking oil mixtures for hybrid diesel production. Fuel 2013, 103, 579-584. [CrossRef]

151. Carmona, H.D.; Alfaro, O.D.; Alayon, A.B.; Vazquez, M.A.R.; Hernandez, J.J.M. Co-processing of straight run gas oil with used cooking oil and animal fats. Fuel 2019, 254, 115583. [CrossRef]

152. Satyarthi, J.K.; Chiranjeevi, T.; Gokak, D.T.; Viswanathan, P.S. Studies on co-processing of jatropha oil with diesel fraction in hydrodesulfurization. Fuel Process. Technol. 2014, 118, 180-186. [CrossRef]

153. Rana, B.S.; Kumar, R.; Tiwari, R.; Kumar, R.; Joshi, R.K.; Garg, M.O.; Sinha, A.K. Transportation fuels from co-processing of waste vegetable oil and gas oil mixtures. Biomass Bioenergy 2013, 56, 43-52. [CrossRef]

154. Chen, J.W.; Farooqi, H.; Fairbridge, C. Experimental Study on Co-hydroprocessing Canola Oil and Heavy Vacuum Gas Oil Blends. Energy Fuel 2013, 27, 3306-3315. [CrossRef]

155. Vonortas, A.; Templis, C.; Papayannakos, N. Effect of Palm Oil Content on Deep Hydrodesulfurization of Gas Oil-Palm Oil Mixtures. Energy Fuel 2012, 26, 3856-3863. [CrossRef]

156. Herrador, J.M.H.; Psenicka, M.; Horacek, J.; Tisler, Z.; Vrablik, A.; Cerny, R.; Murat, M. Co-processing of Waste Cooking Oil and Light Cycle Oil with NiW/(Pseudoboehmite + SBA-15) Catalyst. Chem. Eng. Technol. 2019, 42, 512-517. [CrossRef]

157. Vlasova, E.N.; Porsin, A.A.; Aleksandrov, P.V.; Nuzhdin, A.L.; Bukhtiyarova, G.A. Co-hydroprocessing of straight-run gasoilRapeseed oil mixture over stacked bed $\mathrm{Mo} / \mathrm{Al}_{2} \mathrm{O}_{3}+\mathrm{NiMo} / \mathrm{Al}_{2} \mathrm{O}_{3}-\mathrm{SAPO}-11$ catalysts. Fuel 2021, 285, 115583. [CrossRef]

158. Sebos, I.; Matsoukas, A.; Apostolopoulos, V.; Papayannakos, N. Catalytic hydroprocessing of cottonseed oil in petroleum diesel mixtures for production of renewable diesel. Fuel 2009, 88, 145-149. [CrossRef]

159. Furimsky, E. Metal carbides and nitrides as potential catalysts for hydroprocessing. Appl. Catal. Gen. 2003, 240, 1-28. [CrossRef]

160. Sousa, L.A.; Zotin, J.L.; da Silva, V.T. Hydrotreatment of sunflower oil using supported molybdenum carbide. Appl. Catal. Gen. 2012, 449, 105-111. [CrossRef]

161. Carmona, H.D.; Horacek, J.; Tisler, Z.; Akhmetzyanova, U. Sulfur free supported MoCx and MoNx catalysts for the hydrotreatment of atmospheric gasoil and its blends with rapeseed oil. Fuel 2019, 254, 115582. [CrossRef]

162. Carmona, H.D.; Akhmetzyanova, U.; Tisler, Z.; Vondrova, P. Hydrotreating atmospheric gasoil and co-processing with rapeseed oil using supported Ni-Mo and Co-Mo carbide catalysts. Fuel 2020, 268, 117363. [CrossRef]

163. Wang, F.; Xu, J.M.; Jiang, J.C.; Liu, P.; Li, F.L.; Ye, J.; Zhou, M.H. Hydrotreatment of vegetable oil for green diesel over activated carbon supported molybdenum carbide catalyst. Fuel 2018, 216, 738-746. [CrossRef]

164. Phimsen, S.; Kiatkittipong, W.; Yamada, H.; Tagawa, T.; Kiatkittipong, K.; Laosiripojana, N.; Assabumrungrat, S. Nickel sulfide, nickel phosphide and nickel carbide catalysts for bio-hydrotreated fuel production. Energy Convers. Manag. 2017, 151, 324-333. [CrossRef]

165. Horacek, J.; Akhmetzyanova, U.; Skuhrovcova, L.; Tisler, Z.; Carmona, H.D. Alumina-supported MoNx, MoCx and MoPx catalysts for the hydrotreatment of rapeseed oil. Appl. Catal. B-Environ. 2020, 263, 118328. [CrossRef]

166. Tran, C.C.; Akmach, D.; Kaliaguine, S. Hydrodeoxygenation of vegetable oils over biochar supported bimetallic carbides for producing renewable diesel under mild conditions. Green Chem. 2020, 22, 6424-6436. [CrossRef]

167. Wang, H.L.; Yan, S.L.; Salley, S.O.; Ng, K.Y.S. Support effects on hydrotreating of soybean oil over NiMo carbide catalyst. Fuel 2013, 111, 81-87. [CrossRef]

168. Carmona, H.D.; Svobodova, E.; Tisler, Z.; Akhmetzyanova, U.; Strejcova, K. Hydrotreating of Atmospheric Gas Oil and CoProcessing with Rapeseed Oil Using Sulfur-Free PMoCx/Al2O3 Catalysts. ACS Omega 2021, 6, 7680-7692. [CrossRef] [PubMed]

169. Diaz, B.; Sawhill, S.J.; Bale, D.H.; Main, R.; Phillips, D.C.; Korlann, S.; Self, R.; Bussell, M.E. Hydrodesulfurization over supported monometallic, bimetallic and promoted carbide and nitride catalysts. Catal. Today 2003, 86, 191-209. [CrossRef]

170. Jin, G.Z.; Zhu, J.H.; Fan, X.J.; Sun, G.D.; Gao, J.B. Effect of Ni promoter on dibenzothiophene hydrodesulfurization performance of molybdenum carbide catalyst. Chin. J. Catal 2006, 27, 899-903. [CrossRef]

171. Masudi, A.; Muraza, O. Vegetable Oil to Biolubricants: Review on Advanced Porous Catalysts. Energy Fuel 2018, 32, 10295-10310. [CrossRef]

172. Mobarak, H.M.; Mohamad, E.N.; Masjuki, H.H.; Kalam, M.A.; Al Mahmud, K.A.H.; Habibullah, M.; Ashraful, A.M. The prospects of biolubricants as alternatives in automotive applications. Renew. Sustain. Energy Rev. 2014, 33, 34-43. [CrossRef]

173. Salimon, J.; Salih, N.; Yousif, E. Biolubricants: Raw materials, chemical modifications and environmental benefits. Eur. J. Lipid Sci. Technol. 2010, 112, 519-530. [CrossRef]

174. Chan, C.H.; Tang, S.W.; Mohd, N.K.; Lim, W.H.; Yeong, S.K.; Idris, Z. Tribological behavior of biolubricant base stocks and additives. Renew. Sustain. Energy Rev. 2018, 93, 145-157. [CrossRef] 
175. Fox, N.J.; Stachowiak, G.W. Vegetable oil-based lubricants-A review of oxidation. Tribol. Int. 2007, 40, 1035-1046. [CrossRef]

176. Owuna, F.J.; Dabai, M.U.; Sokoto, M.A.; Dangoggo, S.M.; Bagudo, B.U.; Birnin-Yauri, U.A.; Hassan, L.G.; Sada, I.; Abubakar, A.L.; Jibrin, M.S. Chemical modification of vegetable oils for the production of biolubricants using trimethylolpropane: A review. Egypt. J. Pet. 2020, 29, 75-82. [CrossRef]

177. McNutt, J.; He, Q. Development of biolubricants from vegetable oils via chemical modification. J. Ind. Eng. Chem. 2016, 36, 1-12. [CrossRef]

178. Ghazi, T.I.M.; Resul, M.F.M.G.; Idris, A. Bioenergy II: Production of Biodegradable Lubricant from Jatropha curcas and Trimethylolpropane. Int. J. Chem. React. Eng. 2009, 7. [CrossRef]

179. Koh, M.Y.; Ghazi, T.I.M.; Idris, A. Synthesis of palm based biolubricant in an oscillatory flow reactor (OFR). Ind. Crops Prod. 2014, 52, 567-574. [CrossRef]

180. Masood, H.; Yunus, R.; Choong, T.S.Y.; Rashid, U.; Yap, Y.H.T. Synthesis and characterization of calcium methoxide as heterogeneous catalyst for trimethylolpropane esters conversion reaction. Appl. Catal. Gen. 2012, 425, 184-190. [CrossRef]

181. Sripada, P.K.; Sharma, R.V.; Dalai, A.K. Comparative study of tribological properties of trimethylolpropane-based biolubricants derived from methyl oleate and canola biodiesel. Ind. Crops Prod. 2013, 50, 95-103. [CrossRef]

182. Da Silva, J.A.C.; Habert, A.C.; Freire, D.M.G. A potential biodegradable lubricant from castor biodiesel esters. Lubr. Sci. 2013, 25, 53-61. [CrossRef]

183. Wang, E.P.; Ma, X.; Tang, S.Z.; Yan, R.; Wang, Y.; Riley, W.W.; Reaney, M.J.T. Synthesis and oxidative stability of trimethylolpropane fatty acid triester as a biolubricant base oil from waste cooking oil. Biomass Bioenergy 2014, 66, 371-378. [CrossRef]

184. Sreeprasanth, P.S.; Srivastava, R.; Srinivas, D.; Ratnasamy, P. Hydrophobic, solid acid catalysts for production of biofuels and lubricants. Appl. Catal. Gen. 2006, 314, 148-159. [CrossRef]

185. Kamalakar, K.; Rajak, A.K.; Prasad, R.B.N.; Karuna, M.S.L. Rubber seed oil-based biolubricant base stocks: A potential source for hydraulic oils. Ind. Crops Prod. 2013, 51, 249-257. [CrossRef]

186. Gryglewicz, S.; Muszynski, M.; Nowicki, J. Enzymatic synthesis of rapeseed oil-based lubricants. Ind. Crops Prod. 2013, 45, 25-29. [CrossRef]

187. Kamalakar, K.; Manoj, G.N.V.T.S.; Prasad, R.B.N.; Karuna, M.S.L. Thumba (Citrullus colocynthis L.) seed oil: A potential biolubricant base-stock. Grasas Aceites 2015, 66, e055.

188. Resul, M.F.M.G.; Ghazi, T.I.M.; Idris, A. Temperature Dependence on the Synthesis of Jatropha Biolubricant. In Proceedings of the Conference on Advanced Materials and Nanotechnology (Caman 2009), Wellington, New Zealand, 7-11 February 2011; Volume 17.

189. Menkiti, M.; Anaehobi, H.; Oyoh, K.; Nnaji, P. Process optimization and kinetics of bio-lubricants synthesis from fluted pumpkin seed. Eur. Sci. J. 2015, 11, 1857-7881.

190. Ishak, A.A.; Salimon, J. Synthesis of Rubber Seed Oil and Trimethylolpropane Based Biolubricant Base Stocks. Malays. J. Anal. Sci. 2013, 17, 414-421.

191. Heikal, E.K.; Elmelawy, M.S.; Khalil, S.A.; Elbasuny, N.M. Manufacturing of environment friendly biolubricants from vegetable oils. Egypt. J. Pet. 2017, 26, 53-59.

192. Musa, U.; Mohammed, I.A.; Sadiq, M.M.; Aberuagba, F.; Olurinde, A.O.; Obamina, R. Synthesis and Characterization of Trimethylolpropane-Based Biolubricants from Castor Oil. In Proceedings of the Annual Conference of NSChE, Warri, Nigeria, 7 November 2015.

193. Bethala, L.A.P.D. Ionic Liquids in Lipid Processing and Analysis_Opportunities and Challenges; Elsevier: Amsterdam, The Netherlands, 2016.

194. Cermak, S.C.; Durham, A.L.; Isbell, T.A.; Evangelista, R.L.; Murray, R.E. Synthesis and physical properties of pennycress estolides and esters. Ind. Crops Prod. 2015, 67, 179-184. [CrossRef]

195. Garcia-Zapateiro, L.A.; Franco, J.M.; Valencia, C.; Delgado, M.A.; Gallegos, C.; Ruiz-Mendez, M.V. Chemical, thermal and viscous characterization of high-oleic sunflower and olive pomace acid oils and derived estolides. Grasas Aceites 2013, 64, 497-508.

196. Garcia-Zapateiro, L.A.; Franco, J.M.; Valencia, C.; Delgado, M.A.; Gallegos, C. Viscous, thermal and tribological characterization of oleic and ricinoleic acids-derived estolides and their blends with vegetable oils. J. Ind. Eng. Chem. 2013, 19, 1289-1298. [CrossRef]

197. Biresaw, G.; Bantchev, G.B.; Cermak, S.C. Tribological Properties of Vegetable Oils Modified by Reaction with Butanethiol. Tribol. Lett. 2011, 43, 17-32. [CrossRef]

198. Cermak, S.C.; Brandon, K.B.; Isbell, T.A. Synthesis and physical properties of estolides from lesquerella and castor fatty acid esters. Ind. Crops Prod. 2006, 23, 54-64. [CrossRef]

199. Cermak, S.C.; Bredsguard, J.W.; John, B.L.; McCalvin, J.S.; Thompson, T.; Isbell, K.N.; Feken, K.A.; Isbell, T.A.; Murray, R.E. Synthesis and physical properties of new estolide esters. Ind. Crops Prod. 2013, 46, 386-391. [CrossRef]

200. Cermak, S.C.; Isbell, T.A.; Evangelista, R.L.; Johnson, B.L. Synthesis and physical properties of petroselinic based estolide esters. Ind. Crops Prod. 2011, 33, 132-139. [CrossRef]

201. Salih, N.; Salimon, J.; Yousif, E. The physicochemical and tribological properties of oleic acid based triester biolubricants. Ind. Crops Prod. 2011, 34, 1089-1096. [CrossRef]

202. Silva, M.S.; Foletto, E.L.; Alves, S.M.; Dantas, T.N.D.C.; Neto, A.A.D. New hydraulic biolubricants based on passion fruit and moringa oils and their epoxy. Ind. Crops Prod. 2015, 69, 362-370. [CrossRef] 
203. Sammaiah, A.; Padmaja, K.V.; Prasad, R.B.N. Synthesis of Epoxy Jatropha Oil and its Evaluation for Lubricant Properties. J. Oleo Sci. 2014, 63, 637-643. [CrossRef] [PubMed]

204. Somidi, A.K.R.; Sharma, R.V.; Dalai, A.K. Synthesis of Epoxidized Canola Oil Using a Sulfated-SnO 2 Catalyst. Ind. Eng. Chem. Res. 2014, 53, 18668-18677. [CrossRef]

205. Sharma, B.K.; Doll, K.M.; Erhan, S.Z. Oxidation, friction reducing, and low temperature properties of epoxy fatty acid methyl esters. Green Chem. 2007, 9, 469-474. [CrossRef]

206. Kulkarni, R.D.; Deshpande, P.S.; Mahajan, S.U.; Mahulikar, P.P. Epoxidation of mustard oil and ring opening with 2-ethylhexanol for biolubricants with enhanced thermo-oxidative and cold flow characteristics. Ind. Crops Prod. 2013, 49, 586-592. [CrossRef]

207. Sharma, R.V.; Dalai, A.K. Synthesis of bio-lubricant from epoxy canola oil using sulfated Ti-SBA-15 catalyst. Appl. Catal. B-Environ. 2013, 142, 604-614. [CrossRef]

208. Hwang, H.S.; Erhan, S.Z. Synthetic lubricant basestocks from epoxidized soybean oil and Guerbet alcohols. Ind. Crops Prod. 2006, 23, 311-317. [CrossRef]

209. Li, W.M.; Wang, X.B. Bio-lubricants Derived from Waste Cooking Oil with Improved Oxidation Stability and Low-temperature Properties. J. Oleo Sci. 2015, 64, 367-374. [CrossRef]

210. Kleinova, A.; Fodran, P.; Brncalova, L.; Cvengros, J. Substituted esters of stearic acid as potential lubricants. Biomass Bioenergy 2008, 32, 366-371. [CrossRef]

211. Salimon, J.; Salih, N.; Abdullah, B. Improvement of Physicochemical Characteristics of Monoepoxide Linoleic Acid Ring Opening for Biolubricant Base Oil. J. Biomed. Biotechnol. 2011, 2011, 196565. [CrossRef] [PubMed]

212. Madankar, C.S.; Dalai, A.K.; Naik, S.N. Green synthesis of biolubricant base stock from canola oil. Ind. Crops Prod. 2013, 44, 139-144. [CrossRef]

213. Hashem, A.I.; Abou Elmagd, W.S.I.; Salem, A.E.; El-Kasaby, M.; El-Nahas, A.M. Conversion of Some Vegetable Oils into Synthetic Lubricants via Two Successive Transesterifications. Energy Source Part A 2013, 35, 909-912. [CrossRef] 